\title{
Communication Strategies to Improve Medication Adherence: A Systematic Review of Literature
}

\author{
Kristin G. Maki \\ The University of Texas \\ MD Anderson Cancer Center, USA \\ kmaki@mdanderson.org
}

\author{
Katy A. Harris \\ University at Buffalo \\ The State University of New York, USA \\ katyunde@buffalo.edu
}

\begin{abstract}
Less than optimal medication adherence is a persisting issue among many patient groups, resulting in poorer health outcomes along with increased strain on financial and time resources. However, communication strategies employed by clinicians may offer a simple, cost-effective method for improving medication adherence and health outcomes. We conducted a review of literature that rendered search results from seven databases, resulting in 1,513 abstracts. A final sample of 44 studies was included to compare the effectiveness of communication-based adherence strategies among various health conditions. After reviewing the full text of included studies, we organized communication strategies into four categories: patient reminders, collaborative communication, patient education, and counseling strategies. Although all of the strategies indicated some level of success, studies examining patient education components showed the most promise both in generalizability and results. This review's results indicate that a need remains for quantitative research examining the effectiveness of these strategies to increase medical adherence.
\end{abstract}

\section{Highlights}

- Medication adherence is a persisting problem that affects patients' treatment outcomes for chronic illnesses.

- This review provides an overview of communication strategies that are used within clinical settings to address medication adherence.

- The results show areas with promising results to be adopted by clinicians or further tested by scholars.

- The communication strategies identified include patient reminders, collaborative communication, patient education, and counseling methods (such as motivational interviewing).

- The results show a need for more quantitative and randomized trial-based studies to further develop generalizable results.

Suggested citation: Maki, K. G., \& Harris, K. A. (2021). Communication Strategies to Improve Medication Adherence: A Systematic Review of Literature. Review of Communication Research, 9. 167-192. https://doi.org/10.12840/ISSN.2255-4165.029

Keywords: medication adherence, health communication, patient education as topic, reminder systems, counseling strategies

Editor: Nathan Walter (Northwestern University, USA).

Reviewers: The reviewers prefer to stay anonymous. 


\section{Content}

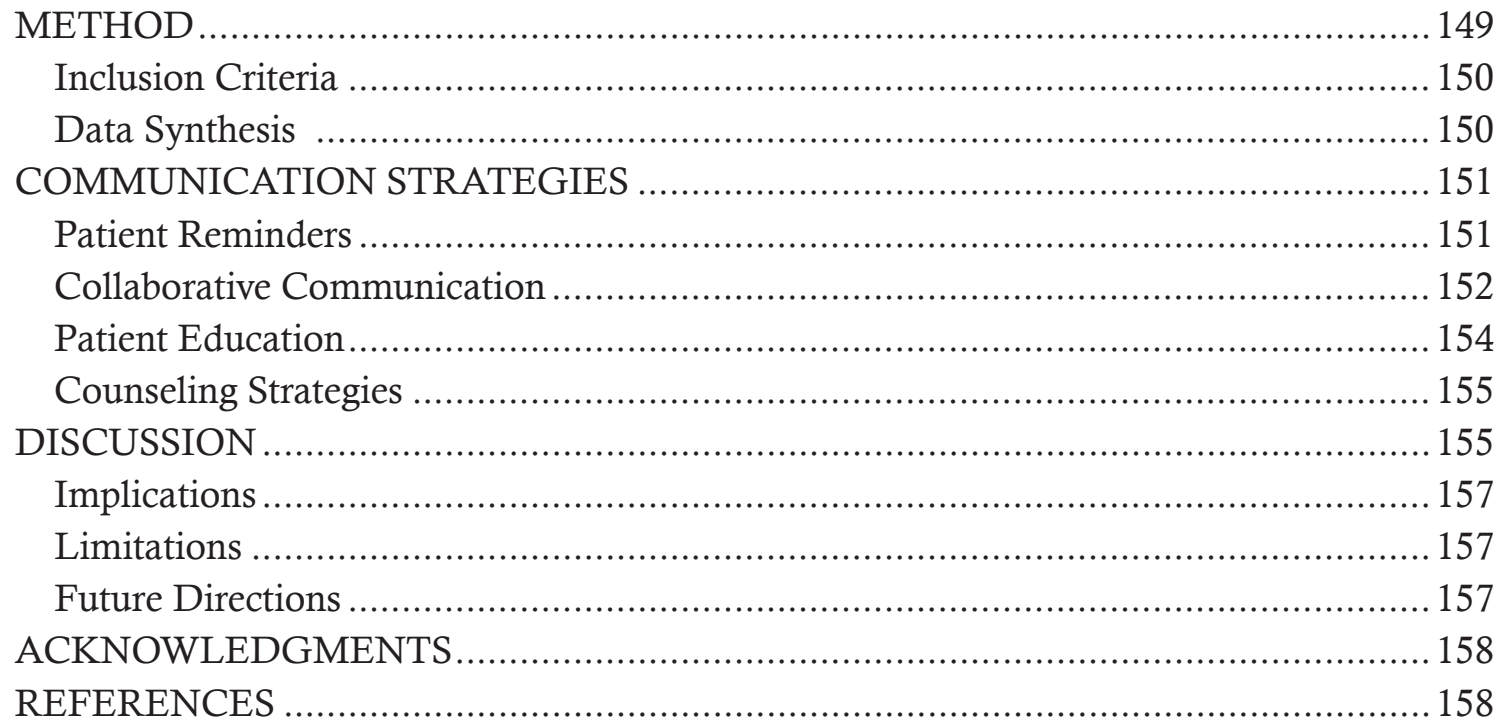

Medical adherence is associated with positive patient outcomes and, as a result, has been studied for many years (Blackwell, 1976). At its core, medical adherence may entail abstaining from certain foods or activities, taking prescribed medications, attending scheduled appointments, or any combination of one or more of these actions (Meichenbaum \& Turk, 1987). Generally speaking, adherence implies following mutually agreed-upon advice regarding one's medical regimen (Haynes \& Sackett, 1979). Adherence incorporates the patient as an active party, rather than a passive recipient of directions. This forms an important distinction when compared with the concepts of compliance and concordance (Bell et al., 2007; Chatterjee, 2006; Cramer et al., 2008; Horne et al., 2005). Specifically, compliance implies the patient's acceptance of the treatment plan despite being passive in its approval (Aronson, 2007; Mihalko et al., 2004), and concordance suggests that the patient and provider both understand which medication is to be taken and is a move toward two-way communication and decision-making (Gray et al., 2002).

Adherence requires that clinicians and patients actively accept and mutually consent to the treatment decision (Blackwell, 1976). As a result, scholars and practitioners have shifted from using the term compliance to focus on patients' adherence when working with chronic illnesses that require a long-term patient-clinician relationship (Chatterjee, 2006;
Horne et al., 2005). Given the patients' autonomy in this situation, there are communication-based strategies clinicians can employ to increase patients' adherence. In this review, we aim to uncover strategies that have shown the most promise in previous research pertaining to medication adherence. Our findings will help guide future research endeavors as well as inform interventions for clinical use.

The literature on this topic reflects contributions from clinical and academic sources representing psychology, sociology, and several other areas. Nonetheless, the field of communication contributed a relatively small amount to this body of research compared to other fields during the time in which medication adherence was beginning to gain attention (Munro et al., 2007). Examples of communication scholars' more recent work related to medication adherence include examining factors such as direct-to-consumer advertising (Im \& Huh, 2018), emotional responses related to antibiotic stewardship (Kim et al., 2019), and health literacy (MayoGamble \& Mouton, 2018). However, given the breadth and applicability of the foundational call to develop health communication research (Kreps, 1989), scholars could add significant value to this area by showing how our field can increase the healthcare system's effectiveness and improve patient outcomes by addressing issues related to non-adherence. Specifically, patients' non-adherence for medication may be due to not understanding the benefits, or having 
inaccurate expectations, related to the treatment. Communication can help in addressing these factors (DiMatteo, 1994).

In addition to communication being a key component of providing patients information, the field has much to offer in terms of improving clinician-patient relationships. For instance, a meta-analysis of predictors for HIV medication adherence showed positive associations between patientclinician trust and satisfaction (Langebeek et al., 2014). Likewise, positive patient-provider interactions may mediate medication self-efficacy, another important predictor of adherence (Johnson et al., 2006). Further, clear communication about factors that affect patients related to their treatment, such as financial cost, has been associated with improved adherence (Meluch \& Oglesby, 2015). Thus, there are several areas in which communication scholars may contribute to improving medication adherence.

Although there are a number of treatment-related activities that may require adherence, this is a review of existing and emerging communication strategies used by clinicians to increase and improve patients' medication adherence. We organized this review by focusing on two research questions: (RQ1) What communication strategies have been implemented to improve medication adherence? (RQ2) Have communication-based strategies been successful in improving medication adherence?

\section{Method}

We completed a comprehensive search of the literature on communication strategies to promote medication adherence (or lessen non-adherence) in various patient populations. Communication strategies were defined as any strategy focusing on a communicative aspect enacted by or with the clinician to increase patients' adherence to a medication regimen. We limited the search to English-language only articles from peer-reviewed journals in the following databases: MEDLINE, PsycARTICLES, Psychology and Behavioral Sciences Collection, PsycINFO, Communication and Mass Media Complete, socINDEX, and Health Source: Nursing/Academic Edition through June 2019. We selected databases through two criteria: (a) available through our institutional library, and (b) related to medical and social science topics. Additional articles were found via citation searching through the Social Sciences Citation Index data- base. The citation search process centers on entering the title of an article of interest (rather than using a search term such as "adherence"); the database retrieves articles that have cited that particular article.

The logic of the search strategy was guided by the PRISMA checklist that provides researchers guidance on conducting systematic reviews where possible (Moher et al., 2010) and follows strategies used by other scholars (Babbie, 2010; Meluch \& Oglesby, 2015). The search strategy is outlined in Figure 1. We began the article selection process by comprehensively searching the databases outlined above with "adherence" as the search term. Additional terms that may be used as a synonym, such as "compliance" or "concordance", were omited due to the magnitude of the results and conceptual distinction evidenced previously (Horne et al., 2005). The term "adherence" rendered 193,166 articles. In an effort to direct the results to the topic of interest, we then included the search term "medication", thereby reducing the articles to 49,751 . To further guide the results, we added "communicat*" as a final search term. This allowed variants of communication, including "communicative" or "communicating", but narrowed the results to 1,226 articles. The search was run again in April 2020, using the process described above, to gather the most current set of articles from the literature prior to completing this manuscript. This search rendered an additional 287 records that were screened for inclusion.

Every abstract was read and screened for inclusion to select the first group of articles that would be reviewed. In the first stage, the authors independently coded a random sample of abstracts ( $n=245,20 \%$ of the initial search results); if the abstracts were selected for further review the articles were read in full. Our inter-rater reliability was acceptable $($ Kappa $=0.77)$ and the remainder of the abstracts $(n=1,268)$ were coded by one reviewer (KM). Following the first level of screening, we read 91 articles in full to assess eligibility. It is noteworthy that none of the articles selected were published in communication journals, despite the inclusion of communication-related variables and strategies. Further, an additional search using the same terms in specific communication journals rendered relatively few articles, with most of them focusing on health literacy or treatment experiences (Lenahan, 2013; Rochon, 2011). After reading the full text of the 91 articles, we included 44 articles in the review. 


\section{Inclusion Criteria}

We used the following inclusion criteria: 1) a specific communication strategy was examined, 2) the study found evidence for the communication strategy's effectiveness in relation to improved medical adherence, and 3) the communication strategy was implemented by a clinician, in contrast to interventions focusing on pharmacists and nonclinical caregivers. Although we had no constraints in place for the date of publication, all of the final 45 studies were published between 1986 and 2018 with reported sample sizes ranging from 10 to 1,588 .

Figure 1. Summary of Search Strategy (back to text)

\section{Data Synthesis}

We read and categorized the studies based on the strategy outlined in each article. The resulting codes were then categorized based on the initial findings. A variety of communication strategies were incorporated within the studies included in the review. These strategies ranged from mobile text messaging reminders (Lewis, 2013) to patient psychoeducation (Prost et al., 2013). Despite the varied methods of incorporating communication in the studies' designs, the communication strategies represented in the articles were categorized into four main groups: 1) patient reminders ( $n=11$ ) (Brath, 2013; Burda, 2012; Hailey, 2013; Hardy, 2011; Lester, 2010; Lewis, 2013; Ownby, 2012; Pop-Eleches, 2011;

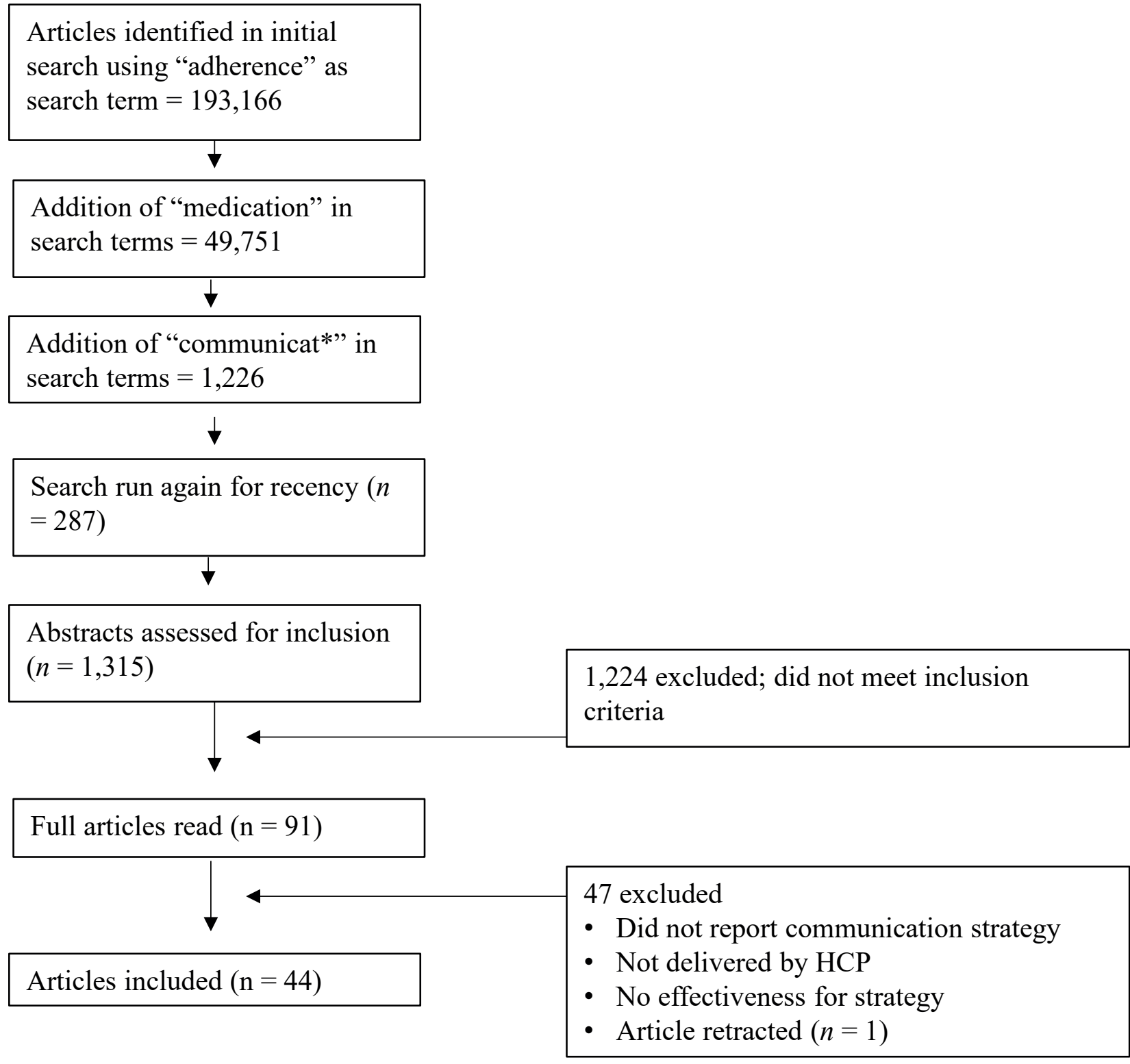


Prost et al., 2013; Safren, 2003; Smillie, 2014; Zolfaghari, 2012), 2) engaging patients with collaborative communication ( $n=14)$ (Bauer, 2014; Bultman, 2000; Ciechanowski, 2001; Cruz, 2013; Heisler, 2007; Polinski, 2014; Quirk, 2013; Roumie, 2011; Schneider, 2004; Schoenthaler, 2009; Sleath, 2012; Tavakoly Sany, 2018; Wachira, 2014; White, 2015), 3) giving information to patients about their medications and medical conditions $(n=15)$ (Barnason, 2010; Bull, 2002; Finocchario-Kessler, 2012; Kekäle, 2016; Morisky et al., 1990; Negarandeh, 2013; Perera, 2014; Prost et al., 2013; Qureshi, 2007; Robinson, 1986; Sanguansak, 2017; Sanmarti et al., 1993; Simon, 2011; Virgolesi, 2017; Windsor, 1990), or 4) counseling strategies such as motivational interviewing $(n=5)$ (Hersch, 2013; McKenzie, 2015; Meglic, 2010; Moral, 2015; Pakpour, 2015).

We grouped the articles based on their primary focus. However, some of the articles incorporated more than one communication strategy, with patient education and reminders being the most frequently combined $(n=8)$ (Kekäle, 2016; Perera, 2014; Sanguansak, 2017; Sanmarti et al., 1993; Simon, 2011; Virgolesi, 2017; White, 2015; Windsor, 1990), followed by counseling strategies paired with patient reminder elements $(n=3)$ (Hersch, 2013; McKenzie, 2015; Meglic, 2010). One article (Ownby, 2012) reported outcomes from intervention groups with reminders and tailored information.

The included studies were conducted with a mix of adolescents and adults representing patients with a variety of conditions, including HIV $(n=12)$ (Finocchario-Kessler, 2012; Hailey, 2013; Hardy, 2011; Hersch, 2013; Lester, 2010; Lewis, 2013; Perera, 2014; Pop-Eleches, 2011; Safren, 2003; Schneider, 2004; Smillie, 2014; Wachira, 2014), diabetes $(n=7)$ (Bauer, 2014; Brath, 2013; Ciechanowski, 2001; Heisler, 2007; Negarandeh, 2013; White, 2015; Zolfaghari, 2012), psychiatric patients including patients with bipolar disorder $(n=6)$ (Burda, 2012; McKenzie, 2015; Prost et al., 2013; Quirk, 2013; Robinson, 1986; Virgolesi, 2017), depression ( $n=5$ ) (Bull, 2002; Bultman, 2000; Cruz, 2013; Meglic, 2010; Simon, 2011), hypertension $(n=5)$ (Polinski, 2014; Qureshi, 2007; Roumie, 2011; Schoenthaler, 2009; Tavakoly Sany, 2018), asthma $(n=2)$ (Sleath, 2012; Windsor, 1990), tuberculosis $(n=2)$ (Morisky et al., 1990; Sanmarti et al., 1993), memory impairment (Ownby, 2012), heart failure (Barnason, 2010), chronic myeloid leukemia (Kekäle, 2016), cataract surgery outpatients (Sanguansak, 2017), epilepsy (Pakpour, 2015), and general chronic disease (Moral, 2015).
A more detailed description of the studies and their participants is included in Table 1.

\section{Communication Strategies}

\section{Patient Reminders}

The logic behind this type of intervention is simple: Either due to resistance or forgetfulness, patients often require a nudge in order to take their medication (Meichenbaum \& Turk, 1987). Although there may be additional barriers, a reminder may be a first step in addressing non-adherence (Perera, 2014). In the case of patient forgetfulness, an intervention that simply sends a reminder about taking medication may help to improve adherence (Tran, 2014). The patient reminder interventions in this review all relied upon technology-based tools to contact patients. As an example of a reminder-based intervention that also included an educational element, a smartphone app was used to inform patients about the effects their medication was having on their condition along with reminding them to follow their medication regimen (Perera, 2014). Likewise, in one of the interventions, participants agreed to receive an automated phone call at set intervals to remind them to take their medication (Ownby, 2012). This prompt was provided in addition to receiving an educational intervention component (Ownby, 2012) that will be discussed in the next section.

In the strictly reminder-based interventions, one study examined the effect of monitoring adherence among homeless patients through daily calls on a cell phone (Burda, 2012). This pilot, quasi-experimental study provided its participants (homeless adults who were prescribed psychotropic medications) with a cell phone for 45 days. The cell phone included free service for personal local and long-distance calls. The participants agreed to receive a phone call every day with a two-item electronic survey asking about their medication intake and side effects. The study had a small sample $(N=10)$, but its results were promising. On average, 93\% of participants were reached each day; when they were reached, they reported taking their medication $100 \%$ of the time. Participants reported that the cell phones' availability helped to improve communication with family members and clinicians through more consistent contact along with re- 
minding them to take their medication (Burda, 2012). Another study examining the effectiveness of SMS reminders distributed cell phones with unlimited texting and minutes to participants (those in the control group received a pager). Its results also support this type of reminder's effectiveness (Hardy, 2011).

Most of the reminder studies used text messaging (Hailey, 2013; Hardy, 2011; Lester, 2010; Lewis, 2013; Pop-Eleches, 2011; Smillie, 2014; Zolfaghari, 2012). All but one of these studies' results (Smillie, 2014) suggest this strategy can be effective and relatively time-efficient. For this type of intervention, patients typically agreed to receive a text message at a set interval — such as every day — to serve as a reminder to take their medication. In some instances (Hailey, 2013; Smillie, 2014), patients were given the responsibility of sending a message verifying they had taken their medication. Additionally, one of the patient education studies (Kekäle, 2016) offered participants an opt-in text message reminder. About one-third of participants opted to receive the reminder, the majority did not find it helpful, and some reported that it was disruptive to their day (i.e., its education components were well-received and participants reported they did not need the text messaging reminder).

In the reminder-based study that did not see positive results in adherence, the barriers (e.g., unstable housing, addiction, mental health issues) may have been too significant to overcome with this kind of strategy (Smillie, 2014). This study was modeled after a multisite randomized trial in Kenya that used a short message service (SMS) format for patients. Its results showed that patients who received the additional support through text messages improved ART adherence and lowered their HIV viral loads (Lester, 2010). The adaptation of this study was carried out at an HIV clinic in Vancouver, British Columbia (Smillie, 2014). The intervention used a weekly SMS based on the original study's intervention; the weekly messages were sent for six months during the study. The reminder system helped participants communicate about challenges - such as getting to the clinic, unstable housing conditions, or addictions-in a more timely fashion than they had previously been able to manage. As a result, although it did not help with medication adherence, patients reported feeling a stronger connection with the clinicians (Smillie, 2014).

One of the most time-intensive interventions included in this review entailed texting teens with HIV (Hailey, 2013). In this intervention, youth in the Baltimore-Metropolitan area who were enrolled in the Special Teens At-Risk Together Reaching, Accessing Care, and Knowledge (STAR TRACK) program were approached for the STAR TRACK Adherence to Medication Program (ST-AMP). Altogether, 87 patients were enrolled in the trial. Overall adherence was approximately 40 to $50 \%$ at baseline. In the ST-AMP program, participants received a daily text message that subtley asked whether they had taken their medication (e.g., "How are you today?"); after taking their medication, the participants sent a response. If a response was not received, followup messages were sent. Next, follow-up messages were sent through social media sites such as Facebook if a response had not been received. As a second stage, if a participant's adherence fell below $80 \%$, a direct observation method was adopted via video messaging. Although this stage of the intervention was only needed for one participant, the added time was noted as a potential limitation. Adherence was measured in this study by patient self-reports, as well as through pharmacy refills, and adherence to clinical appointments. In addition to improving medication adherence, participants reported positive feedback for the usability of text messaging for quick and confidential communication with clinicians (Hailey, 2013).

In spite of potential limitations due to time requirements or inability to address barriers such as financial situation or living conditions, patient reminder systems offer a simple strategy for improving medication adherence. Many of the studies' technology posed a low entry barrier by employing text messaging; this also helped assuage concerns related to privacy. Further, the studies represented in this review offer evidence for the strategy's utility in improving medical adherence as well as fostering a stronger communication system for patients and clinicians. Likewise, reminder systems were built into work that was centered in one of the other groupings (e.g., patient education). Many of the studies within this category were pilot studies or small-scale feasibility testing. Thus, an area for further work is in implementing larger scale trials.

\section{Collaborative Communication}

A positive relationship between the patient and clinican has been noted as an important factor in treatment adherence (Meichenbaum \& Turk, 1987). Although several elements of this relationship may impact treatment adherence, the stud- 
ies included in this review point toward specific strategies that may be beneficial. In general, the more collaboratively clinicians communicate with their patients, the more adherence can be expected (Bauer, 2014; Polinski, 2014). Collaborative communication incorporates factors such as establishing whether the patient prioritizes health, sees the diagnosis as serious, has concerns about the difficulty of following treatment regimens, is afraid of potential side effects, is confident in the treatment's efficacy, and whether the diagnosis is accurate. Implementing this type of collaboration may involve answering patients' questions, not using medical jargon, talking about the treatment's positive and negative aspects, and asking for patients' suggestions and treatment preferences (Meichenbaum \& Turk, 1987).

Showing empathy and positive affect through communication with patients is an important first step. In one study, this aspect of communication was more important in influencing patient adherence than other factors (Cruz, 2013). In this study, psychiatrist-patient dyad interactions were audiorecorded and analyzed using the Roter Interaction Analysis System (RIAS). Seven groupings were created in relation to the patient-centered talk variable: (a) biomedically focused questions related to treatment; (b) psychosocially focused questions (including social and family relations); (c) biomedical-focused information about psychiatric history; (d) psychosocially-focused information (including social and family relations); (e) rapport-building talk such as showing agreement; (f) partnership-building talk such as asking for opinions or clarifications; and (g) facilitators of such (including checking for understanding, providing transitions, and others). This study's findings showed a statistically significant relationship between psychiatrist affect and appointment adherence. However, the length of the appointment and patient-centered talk were not significantly related to appointment adherence (Cruz, 2013).

Along the same vein, addressing patients' concerns and complaints about prescribed medical regimens is important in nurturing therapeutic alliance as well as adherence. For instance, one study's results showed an association between communication, medication adherence, and treatment satisfaction among low-income diabetes patients (White, 2015). In this study, ten health department clinics in the Southern U.S. participated in a trial evaluating an intervention with strategies to improve health communication among 408 lowliteracy diabetes patients. Its strategies included: teaching back, setting goals, reducing use of jargon during appoint- ments, motivational interviewing, and using medical interpreters. In addition to these strategies, clinicians were trained in using a tool kit that was designed to be used in clinical settings with patients who have lower levels of numeracy and literacy. The toolkit's materials were designed for improving patient education about diabetes topics (Wolff et al., 2009). The quality of communication was rated on the clinician's ability to provide information clearly, explain laboratory and clinical findings clearly, effectively discuss patient concerns and involve patients in making decisions, and show compassion and concern for the patient. This study's results showed that better communication was associated with reduced non-adherence among patients as well as treatment satisfaction (White, 2015).

Further, one study indicated that the clinician's initial communication style influences the patient's knowledge and beliefs about the medication. In turn, this may impact patients' future treatment decisions (Bultman, 2000). The clinicians' communication was rated on approachability, instruction, and interactive problem-solving (Bultman, 2000). The study's results showed overall high ratings for clinicians' initial communication styles, including asking about patients' concerns, giving clear instructions, and appearing friendly. Path analysis results showed that initial collaborative communication style predicts a collaborative follow-up communication style; this predicts fewer medication omissions (Bultman, 2000).

Another element of collaboration, discussing non-adherence without judgment or demoralizing the patient, was found to help foster a collaborative treatment regimen. This was also associated with improved adherence (Quirk, 2013). In this study, medical consultations were audio recorded and examined with conversational analysis. Non-adherence was disclosed in $24 \%$ of appointments without being elicited. The psychiatrist's response, however, often allowed a collaborative effort to address the issue. Changing the prescription, either by switching to a different medication or lowering the dose, was the most commonly observed outcome (Quirk, 2013).

Finally, including the patient and/or caregiver in the treatment plan has been shown to be helpful, both for discussing the options for treatment and potential barriers. For instance, involving parent caregivers of asthmatic adolescents in the treatment plan increased adherence and treatment satisfaction in one study. Moreover, involving older adolescent patients in the treatment plan helped address 
treatment obstacles (Sleath, 2012). Each of these elements condenses into a recommendation for clinicians to engage in a collaborative approach with their patients, which may include empathizing with patient concerns, working together to find a solution, sharing information about why a particular medication is prescribed, and letting patients know what to expect (Shea, 2006). Study methodologies in this grouping included analyzing audio recordings from appointments as well as intervention-related work. To further build this area beyond descriptive results, more interventionlevel studies may be needed.

\section{Patient Education}

The importance of sharing information with patients has been suggested for decades (Meichenbaum \& Turk, 1987). Likewise, several of the articles included in this review incorporated elements relating to patient education. It is noteworthy that some studies (Qureshi, 2007; Tavakoly Sany, 2018) included randomized trials of educational interventions for clinicians with the goal of training them to educate patients more effectively. These interventions delivered training on effectively communicating with patients about their health conditions. Follow-up results with survey data from patients suggest that clinicians who received the training provided more information about the patients' condition than those who did not receive the training (Qureshi, 2007; Tavakoly Sany, 2018).

One example of a patient-based intervention provided information about mental illness, and its treatment, to individuals as they waited for their appointments (Prost et al., 2013). The intervention involved formalized psycho-educational components with each clinical visit. These sessions provided information about mental illness while engaging patients' cultural beliefs. The study's results showed a statistically significant improvement for the intervention group's increase in knowledge of mental illness as well as higher medication adherence compared to the control group. These findings provide support for the role of educating patients about an illness in improving adherence (Prost et al., 2013).

In another study, two intervention groups provided tailored information to patients (Ownby, 2012). In one intervention group, participants received a daily reminder telephone call at a time they selected. Participants in the second intervention group responded to a questionnaire on types of in- formation they wanted to receive. Their responses were entered into a computerized program that developed a tailored response reflecting the participants' preferred language, health literacy level, and information requests. The results were printed in an individualized booklet and given to the participants for future use at their homes. A control group was also included in this study design; the participants who were assigned to this condition took part in regular visits and assessments relating to the study but did not receive additional support or information. Compared to the control group, both intervention groups' participants had higher levels of adherence (Ownby, 2012).

In another example, a smartphone app was used to show patients their HIV viral load and their medications' effect in real time (Perera, 2014). In this study, 28 participants were randomized to receive either a standard or augmented version of a smartphone app. The standard version included a 24-hour medication clock showing their daily ART dosing schedule. The augmented version also allowed participants to access graphics representing the estimated plasma concentrations of their medications and personalized simulations of immune activity. The visual impact of the latter function was individualized due to the nature of the ART medications' protective barriers; if the medication is not taken, the barrier breaks down and the virus starts to attack CD4 lymphocytes. Thus, both the plasma level and CD4 images allowed the participants to receive a visual representation of the effects relating to their adherence to ART. The study's results showed higher self-reported adherence in the intervention group than the control group. Further, the intervention group had a significant proportion of participants with a detectable HIV viral load decrease from the baseline measure to the three-month follow-up (26\% to $7 \%$ ); the control group had an opposite result (18\% at baseline went up to $37 \%$ at follow-up). In addition to improved adherence ratings and clinical ratings, the intervention group reported an increase in their understanding of HIV infection and the importance of ART (Perera, 2014).

In sum, whether they were implemented during a counseling session or through a smartphone, each of the interventions aimed toward sharing information with patients showed promising results for increasing medical adherence. This finding aligns with previous research on the effectiveness of patient education in improving adherence (Windsor, 1990). Along with giving information, these interventions provide necessary elements that may help overcome barriers 
to treatment, such as why patients have been prescribed a certain medication, how it works, and how to handle side effects (Bultman, 2000; Sleath, 2012). Finally, it is noteworthy that this grouping contained studies that incorporated patient reminders as part of the intervention design.

\section{Counseling Strategies}

A few studies $(n=5)$ featured counseling strategies, such as motivational interviewing. Although these techniques are distinctly centered in counseling rather than solely a communicative strategy, the studies were included in the present review due to their focus on using these strategies in a patient-provider setting to improve adherence. Motivational interviewing is used within clinical settings to guide behavior change. Rather than using a top-down approach, it involves patients in discussing how they might enact change. Its use is intended to build a constructive patient-provider relationship. This strategy's fundamental pillars are the use of a guiding communication style (rather than directives), eliciting patients' motivations for change through discussion, and developing autonomous decision-making within the patient (Rollnick et al., 2010). Overall, the outcomes from studies that used counseling strategies were promising with increased adherence among a variety of health conditions.

In one example, individuals who were diagnosed with bipolar disorder received a motivational interviewing session at the outpatient psychiatry office where they were a patient. Within this intervention, the motivational interview manual incorporated four principles: express empathy, develop discrepancy, roll with resistance, and support self-efficacy. The goal was to help patients to modify their behaviors, emotions, cognitions, and beliefs about their treatment plans. Following the 45- to 60-minute session, participants were asked to write down concerns they had with their medication, side effects, and doses that were missed. They also scheduled follow-up phone calls that occurred in the next three weeks (McKenzie, 2015). These calls followed a script to ensure consistent content and included decision balance worksheets and plans for continued change. The results showed a statistically significant decrease in medication non-adherence following the intervention (McKenzie, 2015). Similarly, epilepsy patients received motivational interviewing sessions in another study that showed positive results on medication adherence (Pakpour, 2015).
Online counseling was provided in one study, adapted from an in-person cognitive behavioral therapy for adherence (CBT-AD) program (Hersch, 2013). The content used in this study included segments that were tailored to the patient population (HIV-positive individuals) on understanding medication adherence, getting to appointments, communicating with the treatment team, coping with side effects, obtaining medications, the daily medication schedule, storing medications, cue control strategies, and handling slips. The program incorporated photos of the clinician with audio and text to simulate patient-provider interactions. The results showed a significant difference in medication adherence when comparing the intervention and control groups (Hersch, 2013), information and follow-up phone calls (Virgolesi, 2017), and an intervention that combined information about a peak flow meter as well as a one-on-one counseling session, group support sessions, and telephone follow-up calls (Windsor, 1990). It is noteworthy that the context of studies included in this section (i.e., HIV, depression, bipolar disorder, epilepsy, and chronic illness in older adults) may represent conditions that have treatment difficulties, whether from medication side effects or compounding factors. Thus, the counseling strategies may have been selected as an intervention due to the possibility of addressing larger barriers to adherence. As a whole, the counseling strategies produced favorable results in comparison with the control groups for medication adherence throughout the study periods.

\section{Discussion}

In this review, we sought to answer two research questions: What communication strategies have been implemented to improve medication adherence (RQ1)? How successful have they been (RQ2)? To summarize the findings, four main types of communication strategies have been implemented to improve medication adherence. They include patient reminder systems, collaborative communication, patient education, and incorporating counseling strategies such as motivational interviewing. Supporting evidence was found in favor of all of these strategies, although not without limitations. For instance, patient reminders were not effective for helping patients overcome barriers that go beyond forgetfulness (Smillie, 2014). Despite this shortcoming, patient reminders may be a low-cost solution for improving adher- 
ence among patients who do not face significant environmental barriers. For instance, one review found simple reminders to be an effective method for improving adherence to scheduled appointments (Macharia et al., 1992).

Likewise, collaborative communication has been shown as a central determining factor for adherence (Rost et al., 1989). In addition to enabling a conversation, collaborative communication may be a promising strategy because it is a variable the clinician can facilitate (Polinski, 2014). This feature is encouraging because it allows the opportunity for clinicians to improve their patients' outcomes without the need for supplemental interventions or technological tools (Shea, 2006). However, the majority of studies included in this review were survey-based studies rather than interventions with control groups. In one mixed-methods study, psychiatrist-patient interactions were audio-recorded and analyzed (Cruz, 2013). These appointments' themes included biomedical questions and information, psychosocial questions and information, rapport-building talk, partnership-building talk, and facilitators of speech. This shows a good starting point. Yet, although some elements of social support likely would have been included in these conversations, they were not specifically incorporated in the study (Cruz, 2013). However, much work has been done that links social support with beneficial health outcomes, including medication adherence.

For instance, a meta-analysis of 122 studies found a high correlation between practical support and medication adherence with higher levels of adherence among individuals who are in cohesive family situations (DiMatteo, 2004). A qualitative analysis of studies showed similar results, with a key suggestion for providing training for members of a patient's social network with emotional and practical skills to mitigate barriers and bolster confidence related to medication adherence (Scheurer et al., 2012). This highlights an area in which health communication scholars and practitioners could have a significant contribution for improving medication adherence. Potential future work could incorporate training for key members of a patient's social network, developing information that clinicians could give patients to share with members of their social network, or examining the effectiveness of patient navigators within this context.

Further, health communication scholars are well-positioned to contribute expertise to helping clinicians communicate about medical conditions and treatments with a variety of patients, including those who may have lower levels of health literacy. One of the studies included in this review provided clinicians with training in effective health communication, including strategies to improve communication during patient interactions (White, 2015). These included reducing jargon, using teach back, goal setting, motivational interviewing, and using medical interpreters; the clinicians were also trained in using a toolkit that had been developed for use with patients who have lower levels of literacy and numeracy (White, 2015). This study's approaches have some similarities with strategies that have been used with success by other scholars, such as addressing knowledge and comprehension (Sheridan et al., 2011). However, to contrast, many other strategies that have been tested within health communication incorporate message-level factors such as pictorial elements or icon arrays (Sheridan et al., 2011), or narrative elements to help convey information that is designed for patients (Koops van't Jagt et al., 2016).

Patient education is one of the most common strategies employed to improve adherence (McDonald et al., 2002). The reasons for this may include an increased likelihood in patients adhering when they are aware of potential side effects, the severity of their condition and ways to mitigate its effects, and awareness of the treatment's efficacy as well as how it works in promoting their health (Meichenbaum \& Turk, 1987; Shea, 2006). In addition, education strategies allow the opportunity to engage the patient in discussing barriers and ways to work around them as they arise; in turn, this may strengthen the patient-provider relationship and improve clinical outcomes (Shea, 2006). The present review's results show a variety of educational strategies, ranging from informational tools that clinicians can use (Negarandeh, 2013), information sources that can be used primarily by patients on-demand (Perera, 2014), or training interventions to help providers share information in a way that is useful for patients (Qureshi, 2007). This information can also be tailored to meet patient needs and skills, such as being presented in a manner that is accessible for individuals with lower levels of health literacy (Barnason, 2010).

The importance of patient-clinician communication has been highlighted for a number of outcomes (Berkhof et al., 2011). Despite not being a focal point within the present review, patient-clinician communication about financial costs of treatment is an important factor associated with medication adherence (Meluch \& Oglesby, 2015). In addition to improving communication between clinicians and patients, counseling strategies, such as motivational interviewing, 
have become popular in a variety of applications over the years (Miller \& Rollnick, 2009). Although they are typically associated with psychology, the strategies included in the present review rely on communication-related behaviors. Although the adherence outcomes were generally positive, the relatively low number of interventions and the variety of techniques utilized limit the generalizability of results.

\section{Implications}

Considering this review's findings, patient education seems to hold the most promise as a communication-based strategy to improve adherence. Using the studies included in this review as a foundation, the quantitative design of prior research has allowed more generalizable conclusions to be drawn. Although knowledge may only be part of the equation, it serves as a basic starting point for improving medical adherence (Brand et al., 2013). From a clinical standpoint, this may involve estimating patients' health literacy and providing information in an appropriate format, using informational aids such as videos or simplified materials, and providing educational information to supplement an office visit (Brown, 2011). Related, health communication scholars may find several fruitful areas of research and intervention development.

Potential areas for work include developing teach-back methods to be used in clinical settings to help reinforce information that is given by the clinician, developing patientcentered decision support tools that convey information regarding treatment options, and researching implementation opportunities to expand patient education beyond a typical appointment. In addition to providing individuals with more useable information about their treatment, increased knowledge may allow patients to discuss their medical regimens in more detail and with more meaning. As a result, this may lead to a more productive patient-provider relationship that encourages improved outcomes for the patient's wellness (Shea, 2006). Thus, despite the promise that all four strategies have shown, patient education is an important research focus for communication scholars to study further. Specific implications that can be drawn from this review's findings include: (1) the strategy that is employed may vary due to the condition that is being treated; (2) more than one strategy may be employed at once, although including too many may provide spurious results; (3) further empirical research is needed to identify communica- tion strategies that affect adherence.

\section{Limitations}

As with all research, there are some limitations to consider. The articles included were not limited to clinical trials, a range of sample sizes and methodologies were included, and each study conceptualized adherence slightly differently. In addition, given the lack of consistency in terms as well as the expansiveness of the literature, the search was not comprehensive. Finally, this review does not delve into situations in which medication adherence may not be feasible (e.g., cost, side effects, or other individual factors). Despite these limitations, this review has several strengths, including its multidisciplinary search, its focus on communication strategies, and its inclusion of studies that incorporated multiple health conditions.

\section{Future Directions}

This review's findings elucidate a clear need for further work in the realm of health communication related to medication adherence. Specifically, many of the articles included in this review were developed within other fields and would benefit from the application of core behavioral frameworks from the field of communication. In addition, communication scholars could contribute to more nuanced theoretical approaches. Further, none of the articles included in the review explicitly referred to theoretical frameworks' role in developing the intervention or study design. This is likely due to the journal focus and requirements, but reflects an important void for health communication scholars to address. One such area may include the application of entertainment education to convey information to patients effectively. In sum, medication adherence is a multi-faceted issue and its improvement will benefit from a multi-disciplinary approach that includes health communication scholars. 


\section{Acknowledgments}

The authors would like to thank Thomas $\mathrm{H}$. Feeley, $\mathrm{PhD}$, for guidance in the development of this manuscript. Kristin Maki, $\mathrm{PhD}$, is a postdoctoral fellow in the Cancer Prevention Research Training Program and receives a stipend through the Cancer Prevention and Research Institute of Texas grant award, RP170259 (Shine Chang, PhD, Principal Investigator for the Cancer Prevention Research Training Program) and by the MD Anderson Cancer Center Support Grant, CA016672, funded by the National Cancer Institute.

\section{References}

Aronson, J. K. (2007). Compliance, concordance, adherence. British Journal of Clinical Pharmacology, 63(4), 383-384. doi.org/10.1111/j.1365-2125.2007.02893.x

Babbie, E. (2010). The practice of social research (12th ed.).

Barnason, S. Zimmerman, L., Hertzog, M., Schulz, P. (2010). Pilot testing of a medication self-management transition intervention for heart failure patients. Western Journal of Nursing Research, 32(7), 849-870. doi.org/10.1177/0193945910371216

Bauer, A. M., Parker, M.M., Schillinger, D., Katon, W., Adler, N., Adams, A.S., Moffet, H.H., \& Karter, A.J. (2014). Associations between antidepressant adherence and shared decision-making, patient-provider trust, and communication among adults with Diabetes: Diabetes study of Northern California (DISTANCE). JGIM: Journal of General Internal Medicine, 29(8), 1139-1147. doi.org/10.1007/s11606-014-2845-6

Bell, J. S., Airaksinen, M. S., Lyles, A., Chen, T. F., \& Aslani, P. (2007). Concordance is not synonymous with compliance or adherence. British Journal of Clinical Pharmacology, 64(5), 710-711. doi.org/10.1111/j.1365-2125.2007.02971_1.x

Berkhof, M., van Rijssen, H. J., Schellart, A. J., Anema, J. R., \& van der Beek, A. J. (2011). Effective training strategies for teaching communication skills to physicians: An overview of systematic reviews. Patient Education and Counseling, 84(2), 152-162. doi.org/10.1016/j.pec.2010.06.010

Blackwell, B. (1976). Treatment adherence. The British Journal of Psychiatry, 129(6), 513-531. doi.org/10.1192/bjp.129.6.513 Brand, P.L., Klok, T., \& Kaptein, A.A. (2013). Using communication skills to improve adherence in children with chronic disease: The adherence equation. Paediatric Respiratory Reviews, 14(4), 219-223. doi.org/10.1016/j.prrv.2013.01.003

Brath, H., Jürgen, M., Kästenbauer, T., Modre-Osprian, R., Strohner-Kästenbauer, H., Schwarz, M., Kort, W., \& Schreier, G. (2013). Mobile health ( mHealth) based medication adherence measurement - a pilot trial using electronic blisters in diabetes patients. British Journal of Clinical Pharmacology, 76, 47-55. doi.org/10.1111/bcp.12184

Brown, M.T. \& Bussell, J.K. (2011). Medication Adherence: WHO Cares?. Mayo Clinic Proceedings, 86(4), 304-314. doi.org/10.4065/mcp.2010.0575

Bull, S.A., Hu, X.H., Hunkeler, E.M., Lee, J.Y., Ming, E.E., Markson, L.E., \& Fireman, B. (2002). Discontinuation of use and switching of antidepressants: Influence of patient-physician communication. JAMA: Journal of the American Medical Association, 288(11), 1403-1409. doi.org/10.1001/jama.288.11.1403

Bultman, D.C. \& Svarstad, B.L. (2000). Effects of physician communication style on client medication beliefs and adherence with antidepressant treatment. Patient Education and Counseling, 40(2), 173-185. doi.org/10.1016/S0738-3991(99)00083-X

Burda, C., Haack, M., Duarte, A.C., \& Alemi, F. (2012). Medication adherence among homeless patients: A pilot study of cell phone effectiveness. Journal of the American Academy of Nurse Practitioners, 24(11), 675-681. doi.org/10.1111/j.1745-7599.2012.00756.x

Chatterjee, J. (2006). From compliance to concordance in diabetes. Journal of medical ethics, 32(9), 507-510. doi.org/10.1136/jme.2005.012138

Ciechanowski, P.S., Katon, W.J., Russo, J.E., \& Walker, E.A. (2001). The patient-provider relationship: Attachment theory and adherence to treatment in diabetes. The American Journal of Psychiatry, 158(1), 29-35. doi.org/10.1176/appi.ajp.158.1.29

Cramer, J. A., Roy, A., Burrell, A., Fairchild, C. J., Fuldeore, M. J., Ollendorf, D. A., \& Wong, P. K. (2008). Medication 
compliance and persistence: terminology and definitions. Value in Health, 11(1), 44-47.

doi.org/10.1111/j.1524-4733.2007.00213.x

Cruz, M.., Roter, D.L., Cruz, R.F., Wieland, M., Larson, S., Cooper, L.A.,. Pincus, H.A. (2013). Appointment length, psychiatrists' communication behaviors, and medication management appointment adherence. Psychiatric Services, 64(9), 886-892. doi.org/10.1176/appi.ps.201200416

DiMatteo, M. R. (2004). Social support and patient adherence to medical treatment: a meta-analysis. Health Psychology, 23(2), 207-218. doi.org/10.1037/0278-6133.23.2.207

DiMatteo, M. R., Reiter, R.C., \& Gambone, J.C. (1994). Enhancing medication adherence through communication and informed collaborative choice. Health Communication, 6(4), 253. doi.org/10.1207/s15327027hc0604_2

Finocchario-Kessler, S., Catley, D., Thomson, D., Bradley-Ewing, A., Berkley-Patton, J., \& Goggin, K. (2012). Patient communication tools to enhance ART adherence counseling in low and high resource settings. Patient Education and Counseling, 89(1), 163-170. doi.org/10.1016/j.pec.2012.03.020

Gray, R., Wykes, T., \& Gournay, K. (2002). From compliance to concordance: A review of the literature on interventions to enhance compliance with antipsychotic medication. Journal of Psychiatric and Mental Health Nursing, 9(3), 277-284. doi.org/10.1046/j.1365-2850.2002.00474.x

Hailey, J.H.N. \& Arscott, J. (2013). Using technology to effectively engage adolescents and young adults into care: STAR TRACK Adherence Program. Journal of the Association of Nurses in AIDS Care, 24(6), 582-586. doi.org/10.1016/j.jana.2013.03.001

Hardy, H., Kumar, V., Doros, G., Farmer, E., Drainoni, M.L., Rybin, D., Myung, D., Jackson, J., Backman, E., Stanic, A., \& Skolnik, P.R. (2011). Randomized controlled trial of a personalized cellular phone reminder system to enhance adherence to antiretroviral therapy. AIDS Patient Care \& STDs, 25(3), 153-161. doi.org/10.1089/apc.2010.0006

Haynes, R., \& Sackett, D. (1979). Compliance in Health Care Johns Hopkins University Press. Baltimore, MD.

Heisler, M.., Cole, I., Weir, D., Kerr, E.A., \& Hayward, R.A. (2007). Does physician communication influence older patients' Diabetes self-management and glycemic control? Results from the Health and Retirement Study (HRS). Journals of Gerontology Series A: Biological Sciences \& Medical Sciences, 62(12), 1435-1442. doi.org/10.1093/gerona/62.12.1435

Hersch, R.K., Cook, R.F., Billings, D.W., Kaplan, S., Murray, D., Safren, S., Goforth, J., \& Spencer, J. (2013). Test of a webbased program to improve adherence to HIV medications. AIDS and Behavior, 17(9), 2963-2976. doi.org/10.1007/s10461-013-0535-8

Horne, R., Weinman, J., Barber, N., Elliott, R., Morgan, M., Cribb, A., \& Kellar, I. (2005). Concordance, adherence and compliance in medicine taking. London: NCCSDO, 2005, 40-46.

Im, H., \& Huh, J. (2018). Relationship between exposure to direct-to-consumer prescription drug advertising (DTCA) and patients' belief accessibility and medication adherence. Health Communication, 34(9), 975-983. doi.org/10.1080/10410236.2018.1449070

Johnson, M. O., Chesney, M. A., Goldstein, R. B., Remien, R. H., Catz, S., Gore-Felton, C., Charlebois, E., Morin, S. F., \& Team, N. H. L. P. (2006). Positive provider interactions, adherence self-efficacy, and adherence to antiretroviral medications among HIV-infected adults: A mediation model. AIDS Patient Care \& STDs, 20(4), 258-268.

doi.org/10.1089/apc. 2006.20.258

Kekäle, M., Söderlund, T., Koskenvesa, P., Talvensaari, K., \& Airaksinen, M. (2016). Impact of tailored patient education on adherence of patients with chronic myeloid leukaemia to tyrosine kinase inhibitors: A randomized multicentre intervention study. Journal of Advanced Nursing, 72(9), 2196-2206. doi.org/10.1111/jan.12978

Kim, Y., Dillard, J. P., \& Smith, R. A. (2019). Communicating antibiotic stewardship: emotional responses and their impact on adherence. Health Communication, 35(7), 861-871. doi.org/10.1080/10410236.2019.1598615

Koops van't Jagt, R., de Winter, A. F., Reijneveld, S. A., Hoeks, J. C., \& Jansen, C. J. (2016). Development of a communication intervention for older adults with limited health literacy: Photo stories to support doctor-patient communication. Journal of Health Communication, 21(sup2), 69-82. doi.org/10.1080/10810730.2016.1193918

Kreps, G. L. (1989). Setting the agenda for health communication research and development: Scholarship that can make a difference. Health Communication, 1(1), 11-15. doi.org/10.1207/s15327027hc0101_2 
Langebeek, N., Gisolf, E. H., Reiss, P., Vervoort, S. C., Hafsteinsdóttir, T. B., Richter, C., Sprangers, M. A., \& Nieuwkerk, P. T. (2014). Predictors and correlates of adherence to combination antiretroviral therapy (ART) for chronic HIV infection: A meta-analysis. BMC medicine, 12(1), 1-14. doi.org/10.1186/s12916-014-0142-1

Lenahan, J.L., McCarthy, D.M., Davis, T.C., Curtis, L.M., Serper, M., \& Wolf, M.S. (2013). A drug by any other name: Patients' ability to identify medication regimens and its association with adherence and health outcomes. Journal of Health Communication, 18, 31-39. doi.org/10.1080/10810730.2013.825671

Lester, R.T., Ritvo, P., Mills, E.J., Kariri, A., Karanja, S., Chung, M.H., Jack, W., Habyarimana, J., Sadatsafavi, M., Najafzadeh, M., Marra, C.A., Estambale, B., Ngugi, E., Ball, T.B., Thabane, L., Gelmon, L.J., Kimani, J., Ackers, M., \& Plummer, F.A. (2010). Effects of a mobile phone short message service on antiretroviral treatment adherence in Kenya (WelTel Kenya1): A randomised trial. The Lancet, 376(9755), 1838-1845. doi.org/10.1016/S0140-6736(10)61997-6

Lewis, M.A., Uhrig., J.D., Bann, C.M., Harris, J.L., Furberg, R.D., Coomes, C., \& Kuhns, L.M. (2013). Tailored text messaging intervention for HIV adherence: A proof-of-concept study. Health Psychology, 32(3), 248-253. doi.org/10.1037/a0028109

Macharia, W. M., Leon, G., Rowe, B. H., Stephenson, B. J., \& Haynes, R. B. (1992). An overview of interventions to improve compliance with appointment keeping for medical services. JAMA, 267(13), 1813-1817.

doi.org/10.1001/jama.1992.03480130129038

Mayo-Gamble, T. L., \& Mouton, C. (2018). Examining the association between health literacy and medication adherence among older adults. Health Communication, 33(9), 1124-1130. doi.org/10.1080/10410236.2017.1331311

McDonald, H. P., Garg, A. X., \& Haynes, R. B. (2002). Interventions to enhance patient adherence to medication prescriptions: scientific review. JAMA, 288(22), 2868-2879. doi.org/10.1001/jama.288.22.2868

McKenzie, K., Chang,Y.P. (2015). The effect of nurse-led motivational interviewing on medication adherence in patients with bipolar disorder. Perspectives in Psychiatric Care, 51(1), 36-44. doi.org/10.1111/ppc.12060

Meglic, M., Furlan, M., Kuzmanic, M., Kozel, D., Baraga, D., Kuhar, I., Kosir, B., Iljaz, R., Sarotar, B.N., Dernovsek, M.Z., Marusic, A., Eysenbach, G., \& Brodnik, A. (2010). Feasibility of an eHealth service to support collaborative depression care: Results of a pilot study. Journal of Medical Internet Research, 12(5), 123-134. doi.org/10.2196/jmir.1510

Meichenbaum, D., \& Turk, D. C. (1987). Facilitating treatment adherence: A practitioner's guidebook. Plenum Press.

Meluch, A. L., \& Oglesby, W. H. (2015). Physician-patient communication regarding patients' healthcare costs in the US: A systematic review of the literature. Journal of Communication in Healthcare, 8(2), 151-160.

doi.org/ 10.1179/1753807615Y.0000000010

Mihalko, S. L., Brenes, G. A., Farmer, D. F., Katula, J. A., Balkrishnan, R., \& Bowen, D. J. (2004). Challenges and innovations in enhancing adherence. Controlled clinical trials, 25(5), 447-457. doi.org/10.1016/j.cct.2004.07.003

Miller, W. R., \& Rollnick, S. (2009). Ten things that motivational interviewing is not. Behavioural and Cognitive Psychotherapy, 37(2), 129-140. doi.org/10.1017/S1352465809005128

Moher, D., Liberati, A., Tetzlaff, J., \& Altman, D. G. (2010). Preferred reporting items for systematic reviews and metaanalyses: the PRISMA statement. International Journal of Surgery, 8(5), 336-341. doi.org/10.1016/j.ijsu.2010.02.007

Moral, R.R., de Torres, L.A.P., Ortega, L.P., Larumbe, M.C., Villalobos, A.R., García, J.A.F., \& Rejano, J.M.P. (2015). Effectiveness of motivational interviewing to improve therapeutic adherence in patients over 65 years old with chronic diseases: A cluster randomized clinical trial in primary care. Patient Education and Counseling, 98(8), 977-983. doi.org/10.1016/j.pec.2015.03.008

Morisky, D. E., Malotte, C. K., Choi, P., Davidson, P., Rigler, S., Sugland, B., \& Langer, M. (1990). A patient education program to improve adherence rates with antituberculosis drug regimens. Health education quarterly, 17(3), 253-266. doi.org/10.1177/109019819001700303

Munro, S., Lewin, S., Swart, T., \& Volmink, J. (2007). A review of health behaviour theories: how useful are these for developing interventions to promote long-term medication adherence for TB and HIV/AIDS? BMC public health, 7(1), 1-16. doi.org/10.1186/1471-2458-7-104

Negarandeh, R., Mahmoodi, H., Noktehdan, H., Heshmat, R., \& Shakibazadeh, E. (2013). Teach back and pictorial image 
educational strategies on knowledge about diabetes and medication/dietary adherence among low health literate patients with type 2 diabetes. Primary Care Diabetes, 7(2), 111-118. doi.org/10.1016/j.pcd.2012.11.001

Ownby, R.L., Hertzog, C., \& Czaja, S.J. (2012). Tailored information and automated reminding to improve medication adherence in Spanish- and English-Speaking elders treated for memory impairment. Clinical Gerontologist, 35(3), 221-238. doi.org/10.1080/07317115.2012.657294

Pakpour, A.H., Gholami, M., Esmaeili, R., Naghibi, S.A., Updegraff, J.A., Molloy, G.J., \& Dombrowski, S.U. (2015). A randomized controlled multimodal behavioral intervention trial for improving antiepileptic drug adherence. Epilepsy \& Behavior, 52(Part A), 133-142. doi.org/10.1016/j.yebeh.2015.08.036

Perera, A.I., Thomas, M.G., Moore, J.O., Faasse, K., \& Petrie, K.J. (2014). Effect of a smartphone application incorporating personalized health-related imagery on adherence to antiretroviral therapy: A randomized clinical trial. AIDS Patient Care \& STDs, 28(11), 579-586. doi.org/10.1089/apc.2014.0156

Polinski, J.M., Kesselheim, A.S., Frolkis, J.P., Wescott, P., Allen-Coleman, C., \& Fischer, M.A. (2014). A matter of trust: Patient barriers to primary medication adherence. Health Education Research, 29(5), 755-763. doi.org/10.1093/her/cyu023

Pop-Eleches, C.., Thirumurthy, H., Habyarimana, J.P., Zivin, J.G., Goldstein, M.P., de Walque, D., MacKeen, L., Haberer, J., Kimaiyo, S., Sidle, J., Ngare, D., \& Bangsberg, D.R. (2011). Mobile phone technologies improve adherence to antiretroviral treatment in a resource-limited setting: A randomized controlled trial of text message reminders. AIDS, 25(6), 825-834. doi.org/10.1097/QAD.0b013e32834380c1

Prost, E., Musisi, S., Okello, E., \& Hopman, W. (2013). The role of psycho-education in improving outcome at a general hospital psychiatry clinic in Uganda. African Journal of Psychiatry, 16(4), 264-270. doi.org/10.4314/ajpsy.v16i4.35

Quirk, A., Chaplin, R., Hamilton, S., Lelliott, P., \& Seale, C. (2013). Communication about adherence to long-term antipsychotic prescribing: An observational study of psychiatric practice. Social Psychiatry \& Psychiatric Epidemiology, 48(4), 639-647. doi.org/10.1007/s00127-012-0581-y

Qureshi, N.N., Hatcher, J., Chaturvedi, N., \& Jafar, T.H. (2007). Effect of general practitioner education on adherence to antihypertensive drugs: cluster randomised controlled trial. BMJ: British Medical Journal (International Edition), 335(7628), 1030-1033. doi.org/10.1136/bmj.39360.617986.AE

Robinson, G.L., Gilbertson, A.D., \& Litwack, L. (1986). The effects of a psychiatric patient education to medication program on post-discharge compliance. Psychiatric Quarterly, 58(2), 113-118. doi.org/10.1007/BF01064052

Rochon, D., Ross, M.W., Looney, C., Nepal, V.P., Price, A.J., \& Giordano, T.P. (2011). Communication strategies to improve HIV treatment adherence. Health Communication, 26(5), 461-467. doi.org/10.1080/10410236.2011.554168

Rollnick, S., Butler, C. C., Kinnersley, P., Gregory, J., \& Mash, B. (2010). Motivational interviewing. BMJ, 340: c1900. doi.org/10.1136/bmj.c1900

Rost, K., Carter, W., \& Inui, T. (1989). Introduction of information during the initial medical visit: Consequences for patient follow-through with physician recommendations for medication. Social Science \& Medicine, 28(4), 315-321. doi.org/10.1016/0277-9536(89)90032-4

Roumie, C.L., Greevy, R., Wallston, K., Elasy, T., Kaltenbach, L., Kotter, K., Dittus, R., \& Speroff, T. (2011). Patient centered primary care is associated with patient hypertension medication adherence. Journal of Behavioral Medicine, 34(4), 244-253. doi.org/10.1007/s10865-010-9304-6

Safren, S.A., Hendriksen, E.S., Desousa, N., Boswell, S.L., \& Mayer, K.H. (2003). Use of an on-line pager system to increase adherence to antiretroviral medications. AIDS Care, 15(6), 787-793. doi.org/10.1080/09540120310001618630

Sanguansak, T., Morley, K.E., Morley, M.G., Thinkhamrop, K., Thuanman, J., \& Agarwal, I.. (2017). Two-way social media messaging in postoperative cataract surgical patients: Prospective interventional study. Journal of Medical Internet Research, 19(12). doi.org/10.2196/jmir.8330

Sanmarti, L. S., Megias, J. A., Gomez, M. A., Soler, J. C., Alcala, E. N., Puigbo, M. S., \& Majem, L. S. (1993). Evaluation of the efficacy of health education on the compliance with antituberculosis chemoprophylaxis in school children. A randomized clinical trial. Tubercle and lung disease, 74(1), 28-31. doi.org/10.1016/0962-8479(93)90065-6

Scheurer, D., Choudhry, N., Swanton, K. A., Matlin, O., \& Shrank, W. (2012). Association between different types of social 
support and medication adherence. The American journal of managed care, 18(12), e461-467. PMID: 23286676

Schneider, J., Kaplan, S.H., Greenfield, S., Li, W., \& Wilson, I.B. (2004). Better physician-patient relationships are associated with higher reported adherence to antiretroviral therapy in patients with HIV infection. Journal of General Internal Medicine, 19(11), 1096-1103. doi.org/10.1111/j.1525-1497.2004.30418.x

Schoenthaler, A., Chaplin, W.F., Allegrante, J.P., Fernandez, S., Diaz-Gloster, M., Tobin, J.N., \& Ogedegbe, G. (2009). Provider communication effects medication adherence in hypertensive African Americans. Patient Education \& Counseling, 75(2), 185-191. doi.org/10.1016/j.pec.2008.09.018

Shea, S. C. (2006). Improving medication adherence: how to talk with patients about their medications. Lippincott Williams \& Wilkins. Sheridan, S. L., Halpern, D. J., Viera, A. J., Berkman, N. D., Donahue, K. E., \& Crotty, K. (2011). Interventions for individuals with low health literacy: A systematic review. Journal of Health Communication, 16(sup3), 30-54. doi.org/10.1080/10810730.2011.604391

Simon, G.E., Ralston, J.D., Savarino, J., Pabiniak, C., Wentzel, C., \& Operskalski, B.H. (2011). Randomized trial of depression follow-up care by online messaging. Journal of General Internal Medicine, 26(7), 698-704. doi.org/10.1007/s11606-011-1679-8

Sleath, B., Carpenter, D.M., Slota, C., Williams, D., Tudor, G., Yeatts, K., Davis, S., \& Ayala, G.X. (2012). Communication during pediatric asthma visits and self-reported asthma medication adherence. Pediatrics, 130(4), 627-633. doi.org/10.1542/peds.2012-0913

Smillie, K., Van Borek, N., Abaki, J., Pick, N., Maan, E.J., Friesen, K., Graham, R., Levine, S., van der Kop, M.L., Lester, R.T., \& Murray, M. (2014). A Qualitative Study Investigating the Use of a Mobile Phone Short Message Service Designed to Improve HIV Adherence and Retention in Care in Canada (WelTel BC1). Journal of the Association of Nurses in AIDS Care, 25(6), 614-625. doi:10.1016/j.jana.2014.01.008.

Tavakoly Sany, S.B., Payman, N., Behzhad, F., Esmaeily, H., Taghipoor, A., \& Ferns, G. (2018). Health providers' communication skills training affects hypertension outcomes. Medical Teacher, 40(2), 154-163. doi.org/10.1080/0142159X.2017.1395002

Tran, N., Coffman, J.M., Sumino, K., \& Cabana, M.D. (2014). Patient reminder systems and asthma medication adherence: A systematic review. Journal of Asthma, 51(5), 536-543. doi.org/10.3109/02770903.2014.888572

Virgolesi, M., Pucciarelli, G., Colantoni, A.M., D’Andrea, F., Di Donato, B., Giorgi, F., Landi, L., Salustri, E., Turci, C., \& Proietti, M.G. (2017). The effectiveness of a nursing discharge programme to improve medication adherence and patient satisfaction in the psychiatric intensive care unit. Journal of Clinical Nursing, 26(23-24), 4456-4466. doi.org/10.1111/jocn.13776

Wachira, J., Middlestadt, S., Reece, M., Peng, C.Y.J., \& Braitstein, P. (2014). Physician communication behaviors from the perspective of adult HIV patients in Kenya. International Journal for Quality in Health Care, 26(2), 190-197. doi.org/10.1093/intqhe/mzu004

White, R.O., Eden, S., Wallston, K.A., Kripalani, S., Barto, S., Shintani, A., \& Rothman, R.L. (2015). Health communication, self-care, and treatment satisfaction among low-income diabetes patients in a public health setting. Patient Education and Counseling, 98(2), 144-149. doi.org/10.1016/j.pec.2014.10.019

Windsor, R.A., Bailey, W.C., Richards Jr, J.M., Manzella, B., Sen-Jaw, S., \& Brooks, M. (1990). Evaluation of the efficacy and cost effectiveness of health education methods to increase medication adherance among adults with asthma. American Journal of Public Health, 80(12), 1519-1521. doi.org/10.2105/AJPH.80.12.1519

Wolff, K., Cavanaugh, K., Malone, R., Hawk, V., Gregory, B. P., Davis, D., Wallston, K., \& Rothman, R. L. (2009). The Diabetes Literacy and Numeracy Education Toolkit (DLNET). The Diabetes Educator, 35(2), 233-245. doi.org/10.1177/0145721709331945

Zolfaghari, M., Mousavifar, S.A., Pedram, S. \& Haghani, H. (2012). The impact of nurse short message services and telephone follow-ups on diabetic adherence: which one is more effective?. Journal of Clinical Nursing, 21(13-14), 1922-1931. doi.org/10.1111/j.1365-2702.2011.03951.x 
Table 1. Summary of articles (back to text)

\begin{tabular}{|c|c|c|c|c|c|c|c|}
\hline Study & Location & Participants & Age & $N$ & Intervention description & Control group(s) & Duration \\
\hline \multicolumn{8}{|l|}{ Patient Reminders } \\
\hline Brath et al., 2013 & Vienna, Austria & $\begin{array}{l}\text { Patients at a } \\
\text { diabetes outpatient } \\
\text { clinic }\end{array}$ & $\begin{array}{l}69.4(S D \\
=4.75)\end{array}$ & 53 & $\begin{array}{l}\text { Patients received mobile adherence } \\
\text { monitoring electronic blisters for their } \\
\text { medication. If they missed a dose, they } \\
\text { received an SMS reminder. The phyisican } \\
\text { received medication data from a remote } \\
\text { telemonitoring service and could adjust } \\
\text { medication if needed. }\end{array}$ & $\begin{array}{l}\text { Standard } \\
\text { medication blisters, } \\
\text { routine care, and } \\
\text { handwritten } \\
\text { medication intake } \\
\text { diaries. }\end{array}$ & $\begin{array}{l}13 \\
\text { months }\end{array}$ \\
\hline Burda et al., 2012 & $\begin{array}{l}\text { Baltimore, } \\
\text { Maryland, USA }\end{array}$ & $\begin{array}{l}\text { Homeless } \\
\text { psychiatric clients, } \\
\text { prescribed } \\
\text { psychotropic } \\
\text { medications }\end{array}$ & $21-64$ & 10 & $\begin{array}{l}\text { Given cell phone; asked to answer with } \\
\text { daily report on medication adherence. }\end{array}$ & No control group. & 1 month \\
\hline $\begin{array}{l}\text { Hailey \& Arscott, } \\
2013\end{array}$ & $\begin{array}{l}\text { Baltimore, } \\
\text { Maryland (Metro } \\
\text { Area), USA }\end{array}$ & $\begin{array}{l}\text { Clients of STAR } \\
\text { TRACK program, } \\
\text { deemed ready for } \\
\text { ART (HIV) }\end{array}$ & $15-24$ & 87 & $\begin{array}{l}\text { Daily SMS reminders, with two levels of } \\
\text { follow-up (as needed). }\end{array}$ & No control group. & 2 years \\
\hline Hardy et al., 2011 & $\begin{array}{l}\text { Boston, } \\
\text { Massachusetts } \\
\text { (Metro Area), USA }\end{array}$ & $\begin{array}{l}\text { Patients receiving } \\
\text { HIV care in a clinic } \\
\text { located within a } \\
\text { teaching hospital }\end{array}$ & $\begin{array}{l}50.5, \\
\text { range: } \\
35-69\end{array}$ & 23 & $\begin{array}{l}\text { Given cell phone with unlimited calling and } \\
\text { texting plan; assigned a number of daily } \\
\text { reminder texts to match their ART dosing } \\
\text { frequency; replied to text when taking ART }\end{array}$ & $\begin{array}{l}\text { Received a beeper } \\
\text { that would signal } \\
\text { the time to take } \\
\text { ART dose. }\end{array}$ & 6 weeks \\
\hline Lester et al., 2010 & Kenya & $\begin{array}{l}\text { Patients from three } \\
\text { HIV clinics }\end{array}$ & $19-84$ & $\begin{array}{l}538 \text { (intervention } \\
n=273 \text { ) }\end{array}$ & $\begin{array}{l}\text { SMS asking about health status, medication } \\
\text { adherence; follow up call if necessary. }\end{array}$ & $\begin{array}{l}\text { Received standard } \\
\text { care; no SMS. }\end{array}$ & 1 year \\
\hline Lewis et al., 2013 & $\begin{array}{l}\text { Midwest (Region), } \\
\text { USA }\end{array}$ & HIV+ MSM & $25-60+$ & 52 & $\begin{array}{l}\text { Tailored text messages sent to encourage } \\
\text { adherence. }\end{array}$ & No control group. & 3 months \\
\hline $\begin{array}{l}\text { Ownby et al., } \\
2012^{\mathrm{a}}\end{array}$ & $\begin{array}{l}\text { Miami Beach, } \\
\text { Florida, USA }\end{array}$ & $\begin{array}{l}\text { Elderly adults judged } \\
\text { to have significant } \\
\text { memory impairment }\end{array}$ & $71-92$ & $\begin{array}{l}27 \text { (control } n= \\
11, \text { reminders } n \\
=8, \text { tailored, } n= \\
8 \text { ) }\end{array}$ & Reminder group: phone calls daily. & $\begin{array}{l}\text { All study } \\
\text { assessments and } \\
\text { regular monthly } \\
\text { visits. }\end{array}$ & 2 years \\
\hline
\end{tabular}


Table 1. Summary of articles (Continues)

\begin{tabular}{|c|c|c|c|c|c|c|c|}
\hline Study & Location & Participants & Age & $N$ & Intervention description & Control group(s) & Duration \\
\hline \multicolumn{8}{|l|}{ (Patient Reminders) } \\
\hline $\begin{array}{l}\text { Pop-Eleches et } \\
\text { al., } 2011\end{array}$ & $\begin{array}{l}\text { Nyanza Province, } \\
\text { Kenya }\end{array}$ & $\begin{array}{l}\text { Patients who had } \\
\text { initiated ART }<3 \\
\text { months prior to } \\
\text { enrolling in study }\end{array}$ & $\begin{array}{l}\text { Mean } \\
\text { control = } \\
35.65, \\
\text { short } \\
\text { daily = } \\
35.64 \text {, } \\
\text { long daily } \\
=35.73 \text {, } \\
\text { short } \\
\text { weekly = } \\
37.74, \\
\text { long } \\
\text { weekly = } \\
35.76\end{array}$ & $\begin{array}{l}431 \text { (control } n= \\
139 ; \text { short daily } \\
\text { reminder } n= \\
70, \text { long daily } \\
\text { reminder } n= \\
72, \text { short weekly } \\
\text { reminder } n= \\
73, \text { long weekly } \\
\text { reminder } n= \\
74)\end{array}$ & $\begin{array}{l}\text { Short message groups received a message } \\
\text { that translates to "this is your reminder." } \\
\text { The long message groups received, "This is } \\
\text { your reminder. Be strong and courageous, } \\
\text { we care about you." }\end{array}$ & $\begin{array}{l}\text { Received no } \\
\text { messages. }\end{array}$ & 48 weeks \\
\hline $\begin{array}{l}\text { Smillie et al., } \\
2014\end{array}$ & $\begin{array}{l}\text { Vancouver, British } \\
\text { Columbia, Canada }\end{array}$ & $\begin{array}{l}\text { Clients of women-/ } \\
\text { family-centered HIV } \\
\text { clinic }\end{array}$ & $16-60$ & 25 & $\begin{array}{l}\text { Modeled on the WelTel Kenya1 study with } \\
\text { weekly SMS; follow-up if needed. }\end{array}$ & No control group. & 6 months \\
\hline \multicolumn{8}{|c|}{ Collaborative Communication } \\
\hline Bauer et al., 2014 & California, USA & $\begin{array}{l}\text { Adults with Type } 2 \\
\text { diabetes }\end{array}$ & $30-75$ & 1,523 & $\begin{array}{l}\text { Written, web-based, or telephone automated } \\
\text { survey rating the quality of their patient- } \\
\text { provider relationship. }\end{array}$ & No control group. & 1 survey \\
\hline
\end{tabular}


Table 1. Summary of articles (Continues)

\begin{tabular}{|c|c|c|c|c|c|c|c|}
\hline Study & Location & Participants & Age & $N$ & Intervention description & Control group(s) & Duration \\
\hline \multicolumn{8}{|c|}{ (Collaborative Communication) } \\
\hline $\begin{array}{l}\text { Bultman \& } \\
\text { Svarstad, } 2000\end{array}$ & Wisconsin, USA & $\begin{array}{l}\text { Adults with newly } \\
\text { prescribed } \\
\text { antidepressant }\end{array}$ & $18-84$ & 100 & $\begin{array}{l}\text { Interview on knowledge and beliefs about } \\
\text { antidepressants; beliefs about physician's } \\
\text { initial communication style. } \\
\text { Second interview on medication use, } \\
\text { physician follow-up communication, } \\
\text { satisfaction with medication, and } \\
\text { adherence. }\end{array}$ & No control group. & 2 months \\
\hline $\begin{array}{l}\text { Ciechanowski et } \\
\text { al., } 2001\end{array}$ & $\begin{array}{l}\text { Puget Sound, } \\
\text { Washington, USA }\end{array}$ & $\begin{array}{l}\text { English-speaking } \\
\text { adults with type } 1 \text { or } \\
2 \text { diabetes, enrolled } \\
\text { in HMO for } 2+ \\
\text { years and had } 3+ \\
\text { visits with HCP }\end{array}$ & $\begin{array}{l}61.3(S D \\
=11.9)\end{array}$ & 367 & $\begin{array}{l}\text { Questionnaire with scales for provider's } \\
\text { affective and informative behaviors, as well } \\
\text { as quality of communication. }\end{array}$ & $\begin{array}{l}\text { Compared patients } \\
\text { who had rated } \\
\text { providers as good } \\
(n=246) \text { vs. poor } \\
(n=110)\end{array}$ & $\begin{array}{l}\text { Cross- } \\
\text { sectional }\end{array}$ \\
\hline Cruz et al., 2013 & $\begin{array}{l}\text { Midwest (Region), } \\
\text { USA }\end{array}$ & $\begin{array}{l}\text { Psychiatric clients } \\
\text { who were diagnosed } \\
\text { with depression }\end{array}$ & $24-65$ & 107 & $\begin{array}{l}\text { Visit communication analyzed with Roter } \\
\text { Interaction Analysis System (RIAS). } \\
\text { Variable was calculated for patient-centered } \\
\text { talk. Emotional tone was also rated, and } \\
\text { appointment length was recorded. }\end{array}$ & No control group. & $\begin{array}{l}\text { Cross- } \\
\text { sectional } \\
\text { study }\end{array}$ \\
\hline $\begin{array}{l}\text { Heisler et al., } \\
2007\end{array}$ & $\begin{array}{l}\text { USA (Nationally } \\
\text { representative } \\
\text { sample) }\end{array}$ & $\begin{array}{l}\text { Health and } \\
\text { Retirement Study } \\
\text { participants with } \\
\text { diabetes }\end{array}$ & $\begin{array}{l}69(S D= \\
8.65)\end{array}$ & 1588 & $\begin{array}{l}\text { Survey with validated measures of provider } \\
\text { communication styles. }\end{array}$ & No control group. & $\begin{array}{l}\text { Cross- } \\
\text { sectional } \\
\text { study }\end{array}$ \\
\hline $\begin{array}{l}\text { Polinski et al., } \\
2014\end{array}$ & $\begin{array}{l}\text { Northeast (Region) } \\
\text { USA }\end{array}$ & $\begin{array}{l}\text { Patients who did not } \\
\text { pick up hypertension } \\
\text { prescription within } \\
30 \text { days after fill date }\end{array}$ & $35-81$ & 26 & $\begin{array}{l}\text { Focus groups discussed attitudes and } \\
\text { experiences relating to diagnosis of } \\
\text { hypertension. Barriers to adherence and } \\
\text { preferences for shared decision-making } \\
\text { discussed. }\end{array}$ & No control group. & $\begin{array}{l}\text { Cross- } \\
\text { sectional } \\
\text { study }\end{array}$ \\
\hline Quirk et al., 2013 & United Kingdom & $\begin{array}{l}\text { Psychiatric } \\
\text { outpatient clinic } \\
\text { clients }\end{array}$ & $\begin{array}{l}\text { HCP:43- } \\
52 \\
\text { Patients: } \\
19-65\end{array}$ & 92 & $\begin{array}{l}\text { Conversational analysis of audio recorded, } \\
\text { transcribed appointments; patients' } \\
\text { expectations of the consultation recorded } \\
\text { with pre-consultation questionnaire. }\end{array}$ & No control group. & $\begin{array}{l}\text { Cross- } \\
\text { sectional } \\
\text { study }\end{array}$ \\
\hline
\end{tabular}


Table 1. Summary of articles (Continues)

\begin{tabular}{|c|c|c|c|c|c|c|c|}
\hline Study & Location & Participants & Age & $N$ & Intervention description & Control group(s) & Duration \\
\hline \multicolumn{8}{|c|}{ (Collaborative Communication) } \\
\hline $\begin{array}{l}\text { Roumie et al., } \\
2011\end{array}$ & Tennessee, USA & $\begin{array}{l}\text { Veterans who had } \\
\text { participated in a } \\
\text { prior cluster } \\
\text { randomized trial, } \\
\text { treated for } \\
\text { hypertension }\end{array}$ & $\begin{array}{l}63.4(S D= \\
12.7)\end{array}$ & 756 & $\begin{array}{l}\text { Participants received a mailed survey that } \\
\text { included a primary care assessment survey } \\
\text { as well as medication adherence ratings. }\end{array}$ & No control group. & 6 months \\
\hline $\begin{array}{l}\text { Schneider et al., } \\
2004\end{array}$ & $\begin{array}{l}\text { Boston (Metro } \\
\text { Area), } \\
\text { Massachusetts, } \\
\text { USA }\end{array}$ & $\begin{array}{l}\text { Patients who were } \\
\text { diagnosed with HIV }\end{array}$ & $\begin{array}{l}41.6(S D= \\
7.7)\end{array}$ & 554 & $\begin{array}{l}\text { Patients were surveyed on demographics, } \\
\text { interpersonal care, medication adherence, } \\
\text { and quality of physician-patient } \\
\text { relationships. }\end{array}$ & No control group. & $\begin{array}{l}\text { Cross- } \\
\text { sectional } \\
\text { survey }\end{array}$ \\
\hline $\begin{array}{l}\text { Schoenthaler et } \\
\text { al., } 2009\end{array}$ & $\begin{array}{l}\text { New York City } \\
\text { (Metro Area), USA }\end{array}$ & $\begin{array}{l}\text { Patients with poorly } \\
\text { controlled } \\
\text { hypertension }\end{array}$ & $25-98$ & 439 & $\begin{array}{l}\text { Conducted as part of CAATCH trial. } \\
\text { Participants rated HCPs' communication } \\
\text { and reported medication adherence with a } \\
\text { questionnaire. }\end{array}$ & No control group. & $\begin{array}{l}\text { Cross- } \\
\text { sectional } \\
\text { study }\end{array}$ \\
\hline Sleath et al., 2012 & $\begin{array}{l}\text { North Carolina, } \\
\text { USA }\end{array}$ & $\begin{array}{l}\text { Children with } \\
\text { Asthma and their } \\
\text { caregivers }\end{array}$ & $8-16$ & 259 & $\begin{array}{l}\text { Medical visits were audio-taped and children } \\
\text { were interviewed one month after their } \\
\text { appointment. }\end{array}$ & No control group. & 1 month \\
\hline $\begin{array}{l}\text { Tavakoly Sany et } \\
\text { al., } 2018\end{array}$ & Mashhad, Iran & $\begin{array}{l}\text { Patients with } \\
\text { hypertension }\end{array}$ & $\begin{array}{l}54.8(S D= \\
11.5)\end{array}$ & 240 & $\begin{array}{l}\text { Healthcare providers received three sessions } \\
\text { of focus-group discussion and two training } \\
\text { workshops to identify patient needs, barriers, } \\
\text { beliefs, and ideas consistent with patient } \\
\text { centered couseling. Health literacy was } \\
\text { addresseed as well. }\end{array}$ & Usual care. & Not reported \\
\hline $\begin{array}{l}\text { Wachira et al., } \\
2014\end{array}$ & Kenya & Patients with HIV & $\begin{array}{l}\text { Median } 38, \\
\text { range } 33-44\end{array}$ & 400 & $\begin{array}{l}\text { Patients were surveyed about socio- } \\
\text { demographic characteristics; health status, } \\
\text { healthcare system factors; and patient- } \\
\text { provider relationship. }\end{array}$ & No control. & $\begin{array}{l}\text { Cross- } \\
\text { sectional } \\
\text { survey }\end{array}$ \\
\hline
\end{tabular}


Table 1. Summary of articles (Continues)

\begin{tabular}{|c|c|c|c|c|c|c|c|}
\hline Study & Location & Participants & Age & $N$ & Intervention description & Control group(s) & Duration \\
\hline \multicolumn{8}{|c|}{ (Collaborative Communication) } \\
\hline $\begin{array}{l}\text { White et al., } \\
2015^{\mathrm{a}}\end{array}$ & Tennessee, USA & $\begin{array}{l}\text { Patients with Type } 2 \\
\text { diabetes }\end{array}$ & $30-68$ & 408 & $\begin{array}{l}\text { Ten state health department clinics randomly } \\
\text { assigned. Intervention site HCPs exposed to } \\
\text { training in effective health communication. }\end{array}$ & $\begin{array}{l}\text { HCPs given } \\
\text { evidence-based } \\
\text { updates in T2D } \\
\text { care and materials } \\
\text { to share with } \\
\text { patients. }\end{array}$ & 2 years \\
\hline
\end{tabular}

\section{Patient Education}

\section{Barnason et al.,}

2010

Midwest (Region),

USA

\section{Patients who were}

hospitalized due to

heart failure

$76.9(S D$

40 (inter-

$=6.5)$

range:

20)

$65-92$

(e.

rials were provided based on this information

(e.g., adapted versions of information for health

literacy). Three modules of intervention materials were delivered by telephone in educational and coaching sessions.

Bull et al., $2002 \quad$ Northern

California

(Region), USA

Finocchario- Kansas City,

Kessler et al., 2012 Missouri, USA
Patients who recent-

ly began taking a

$45.8(S D$

selective serotonin

reuptake inhibitor

for depression

HIV+ urban clinic

patients

401

Participants were surveyed about their patientprovider communication about medication as well as their medication behavior.

$22-48$

Chronic phase adult 58.3 , patients with chronic range: myeloid leukemia

Participants received 10 counseling sessions ( 6 face-to-face, 4 phone) over 24 weeks; aimed to provide info, enhance motivation, and develop problem solving skills to increase ART adherence. vention $n=$ ducted counsling and interactive information
Kekäle et al., $\quad$ Finland $2016^{\mathrm{b}}$
Usual care plus face-to-face interactions to assess

baseline data. Individualized intervention mate-

\section{Usual care for \\ 1 and 3 \\ patient education \\ with verbal \\ instruction}

reinforcing key

content in an

education booklet.

No control group.

Crosssectional survey

68 (inter- $\quad$ Tailored patient education combining nurse-con35) technologies. Educational content (vidoe, booklet, and website) were available online. Participants could opt-in to reminder text messages.

\section{Standard medical 6 months}

care.

Usual care.

9 months 
Table 1. Summary of articles (Continues)

\begin{tabular}{|c|c|c|c|c|c|c|c|}
\hline Study & Location & Participants & Age & $N$ & Intervention description & Control group(s) & Duration \\
\hline \multicolumn{8}{|c|}{ (Patient Education) } \\
\hline $\begin{array}{l}\text { Morisky et } \\
\text { al., } 1990\end{array}$ & $\begin{array}{l}\text { Hollywood- } \\
\text { Wilshire Health } \\
\text { District } \\
\text { (California, USA) }\end{array}$ & $\begin{array}{l}\text { Patients with active } \\
\text { Tuberculosis as well } \\
\text { as preventive pa- } \\
\text { tients with no evi- } \\
\text { dence of the disease }\end{array}$ & $18-81$ & $\begin{array}{l}205 \text { (active } \\
\text { TB } n=88 \text { ) }\end{array}$ & $\begin{array}{l}\text { Health education counseling and an incentive } \\
\text { (such as bus tokens, food coupons, movie tickets, } \\
\text { or cash) at each visit. }\end{array}$ & $\begin{array}{l}\text { Standard clinic } \\
\text { treatment. }\end{array}$ & 2 years \\
\hline $\begin{array}{l}\text { Negarandeh } \\
\text { et al., } 2013\end{array}$ & Saqquez, Iran & $\begin{array}{l}\text { Patients with type } 2 \\
\text { diabetes who had } \\
\text { low health literacy }\end{array}$ & $\begin{array}{l}\text { Control } \\
49.12(S D= \\
8.78) \\
\text { Pictorial } \\
51.00(S D= \\
9.74) \\
\text { Teach-back } \\
50.27(S D= \\
8.52)\end{array}$ & $\begin{array}{l}127 \\
(\text { control } n \\
=40 \\
\text { pictorial } n \\
=44 \\
\text { teach-back } \\
n=43)\end{array}$ & $\begin{array}{l}\text { Pictorial: Three weekly educational sessions with } \\
\text { simple, realistic pictures that were combined } \\
\text { with existing educational materials. } \\
\text { Teach-back: Three weekly educational sessions } \\
\text { in which explanations were given with plain } \\
\text { language. Participants were asked to repeat } \\
\text { things back to make sure the instructor explained } \\
\text { it clearly. }\end{array}$ & $\begin{array}{l}\text { Usual care: routine } \\
\text { patient education } \\
\text { given in a } \\
\text { brochure. }\end{array}$ & 6 weeks \\
\hline $\begin{array}{l}\text { Perera et al., } \\
2014^{\text {b }}\end{array}$ & New Zealand & $\begin{array}{l}\text { Patients with HIV, } \\
\text { on ART for at least } 6 \\
\text { months }\end{array}$ & $30-65$ & $\begin{array}{l}\mathrm{N}=28 \\
(\text { male } n= \\
26)\end{array}$ & $\begin{array}{l}\text { Access to augmented version of app with } \\
\text { personalized health-related imagery. Plasma } \\
\text { level of drugs and immune activity imagery } \\
\text { changed in response entering dose-taking into } \\
\text { app. }\end{array}$ & $\begin{array}{l}\text { Standard version of } \\
\text { the app with } 24- \\
\text { hour med clock } \\
\text { showing ART } \\
\text { dosing schedule. }\end{array}$ & 3 months \\
\hline $\begin{array}{l}\text { Prost et al., } \\
2013\end{array}$ & Uganda & $\begin{array}{l}\text { Psychiatric } \\
\text { outpatients with all } \\
\text { diagnoses }\end{array}$ & $17-85$ & $\begin{array}{l}\mathrm{N}=117 \\
\text { (interven- } \\
\text { tion } n= \\
64 \text { ) }\end{array}$ & $\begin{array}{l}\text { Pyschoeducation sessions given while partici- } \\
\text { pants and family members waited to see clini- } \\
\text { cians. Sessions addressed basic characteristics of } \\
\text { mental disorders, cultural aspects of mental } \\
\text { illness, and treatments. }\end{array}$ & $\begin{array}{l}\text { Standard care with } \\
\text { no psycho- } \\
\text { education sessions. }\end{array}$ & 3 months \\
\hline $\begin{array}{l}\text { Qureshi et } \\
\text { al., } 2007\end{array}$ & Karachi, Pakistan & $\begin{array}{l}\text { Patients seeking care } \\
\text { from general } \\
\text { practitioners for } \\
\text { hypertension }\end{array}$ & 55.3 & $\begin{array}{l}200 \text { (inter- } \\
\text { vention } n= \\
1000)\end{array}$ & $\begin{array}{l}\text { General practitioners received training on hyper- } \\
\text { tension. Course components included behavioral } \\
\text { and pharmacological interventions; low-cost and } \\
\text { appropriate generic drugs; single dose drug regi- } \\
\text { mens; follow-up visits; stepped care approach; } \\
\text { and consultation for patients with explanations } \\
\text { of treatment and communication strategies. }\end{array}$ & $\begin{array}{l}\text { Usual care (general } \\
\text { practitioners in the } \\
\text { community). }\end{array}$ & 6 weeks \\
\hline
\end{tabular}


Table 1. Summary of articles (Continues)

\begin{tabular}{|c|c|c|c|c|c|c|c|}
\hline Study & Location & Participants & Age & $N$ & Intervention description & Control group(s) & Duration \\
\hline \multicolumn{8}{|l|}{ (Patient Education) } \\
\hline $\begin{array}{l}\text { Robinson et al., } \\
1986\end{array}$ & Akron, Ohio, USA & $\begin{array}{l}\text { Psychiatric patients } \\
\text { ready for discharge }\end{array}$ & $\begin{array}{l}\text { Not } \\
\text { reported }\end{array}$ & 150 & $\begin{array}{l}\text { Intervention group 1: } 1-2 \text { page medication } \\
\text { information sheet. } \\
\text { Intervention group 2: Medication sheets (like } \\
\text { group 1), plus verbal review of information with } \\
\text { trained reviewer. }\end{array}$ & $\begin{array}{l}\text { Standard } \\
\text { education, } \\
\text { generally } \\
\text { consisting of } \\
\text { explanations/ } \\
\text { warning. }\end{array}$ & $\begin{array}{l}1-3 \\
\text { weeks } \\
\text { post- } \\
\text { discharge }\end{array}$ \\
\hline $\begin{array}{l}\text { Sanguansak et al., } \\
2017^{\mathrm{b}}\end{array}$ & $\begin{array}{l}\text { Khon Kaen, } \\
\text { Thailand }\end{array}$ & $\begin{array}{l}\text { Patients } \\
\text { recommended to } \\
\text { have outpatient } \\
\text { cataract surgery }\end{array}$ & $\begin{array}{l}<65 n= \\
48,>65 n \\
=50\end{array}$ & $\begin{array}{l}98 \text { (inter- } \\
\text { vention } n= \\
49 \text { ) }\end{array}$ & $\begin{array}{l}\text { Intervention group received } 9 \text { educational } \\
\text { messages with content about hand and face } \\
\text { hygience, medication instillation and adherence, } \\
\text { visit reminders and adherence, medication } \\
\text { reminders, and medication tapering schedule. } \\
\text { They also received a link to educational videos } \\
\text { about pre-/post-op eye care and use of drops to } \\
\text { watch on demand. }\end{array}$ & $\begin{array}{l}\text { Standard pre-/ } \\
\text { post-op education, } \\
\text { which included } \\
\text { watching } 4 \\
\text { educational videos } \\
\text { in the clinic. }\end{array}$ & 30 days \\
\hline $\begin{array}{l}\text { Sanmarti et al., } \\
1993^{\text {b }}\end{array}$ & Barcelona, Spain & $\begin{array}{l}\text { Tuberculin-positive } \\
\text { children in the first } \\
\text { year of primary } \\
\text { education who did } \\
\text { not have active } \\
\text { Tuberculosis }\end{array}$ & Mean 6.5 & $\begin{array}{l}\mathrm{N}=319 \\
\text { (control } \\
\text { group } n= \\
77 \text { ) }\end{array}$ & $\begin{array}{l}\text { Intervention group 1: mothers received telephone } \\
\text { calls from specialized nursing staff every } 3 \\
\text { months. } \\
\text { Intervention group 2: in-home health education. } \\
\text { Intervention group 3: educational messages from } \\
\text { doctor every } 3 \text { months, during an appointment. }\end{array}$ & $\begin{array}{l}\text { Patients informed } \\
\text { they did not need to } \\
\text { return after first } \\
\text { visit until the } \\
\text { treatment had been } \\
\text { followed for } 1 \text { year. }\end{array}$ & 1 year \\
\hline Simon et al., $2011^{\mathrm{b}}$ & $\begin{array}{l}\text { Washington (state), } \\
\text { USA }\end{array}$ & $\begin{array}{l}\text { Patients starting } \\
\text { treatment for } \\
\text { depression }\end{array}$ & 40 & 208 & $\begin{array}{l}\text { Welcome message with program description and } \\
\text { advice about medication and self-care for } \\
\text { depression. Monitoring contacts were scheduled } \\
(2,6 \text {, and } 10 \text { weeks later). Each monitoring } \\
\text { contact had an outeach message and an online } \\
\text { assessment. An algorithm generated a suggested } \\
\text { response based on the information entered in the } \\
\text { assessment and the care manager could tailor the } \\
\text { response using information in the medical record } \\
\text { or prior messages. }\end{array}$ & Usual care. & 5 months \\
\hline
\end{tabular}


Table 1. Summary of articles (Continues)

\begin{tabular}{|c|c|c|c|c|c|c|c|}
\hline Study & Location & Participants & Age & $N$ & Intervention description & Control group(s) & Duration \\
\hline \multicolumn{8}{|c|}{ (Patient Education) } \\
\hline $\begin{array}{l}\text { Virgolesi et al., } \\
2017^{\mathrm{b}}\end{array}$ & Rome, Italy & $\begin{array}{l}\text { Patients admitted to } \\
\text { psychiatric intensive care } \\
\text { units and discharged } \\
\text { with longterm } \\
\text { medication plan (and } \\
\text { met eligibility criteria) }\end{array}$ & $\begin{array}{l}33.2(S D \\
=7.9)\end{array}$ & 135 & $\begin{array}{l}\text { [Nurses were trained prior to beginning } \\
\text { intervention.] Patients had a structured interview } \\
\text { with a nurse during the discharge process. This } \\
\text { included information about the prescribed } \\
\text { medication, its benefits, effects, and } \\
\text { administration. The nurse also gave the patient a } \\
\text { written summary of medication doses and } \\
\text { schedule. Patients received the initial supply of } \\
\text { medication upon discharge and received a } \\
\text { follow-up phone call 7-10 days after discharge. }\end{array}$ & No control group. & 7-10 days \\
\hline $\begin{array}{l}\text { Windsor et al., } \\
1990^{\mathrm{b}}\end{array}$ & $\begin{array}{l}\text { Southern } \\
\text { (Region) USA }\end{array}$ & $\begin{array}{l}\text { Patients who had a } \\
\text { primary diagnosis of } \\
\text { Asthma }\end{array}$ & $\begin{array}{l}\text { Median } \\
49-50\end{array}$ & $\begin{array}{l}\mathrm{N}=267 \\
\text { (interven- } \\
\text { tion } n= \\
132 \text { ) }\end{array}$ & $\begin{array}{l}\text { Received a peak flow meter and standardized } \\
\text { program with } 30 \text {-minute informational one-on- } \\
\text { one session; a } 60 \text {-minute asthma support group } \\
\text { session; and two telephone reinforcement calls } \\
\text { within one month of the group session. }\end{array}$ & $\begin{array}{l}\text { Baseline and } \\
\text { 12-month follow- } \\
\text { up. }\end{array}$ & 1 year \\
\hline
\end{tabular}

Counseling Strategies

\section{Hersch et al., \\ Urban clinic, \\ Patients who were HIV+}

$2013^{\mathrm{b}}$

USA

and had not been active-

ly engaged in the clinic's

medication adherence

case mangement pro-

gram for at least 6

months

McKenzie \&

Chang, 2015

\section{Western NY Patients diagnosed with}

(Region), USA bipolar disorder,

prescribed $\geq 1$ medication,

and had a medication

adherence rate of $80 \%$ or

less on timeline

followback

\begin{tabular}{|c|c|c|c|c|}
\hline $19-69$ & $\begin{array}{l}168 \\
\text { (control } n \\
=79)\end{array}$ & $\begin{array}{l}\text { Web-based Life-Steps for Managing Medications } \\
\text { and Stress, based on a cognitive behavioral } \\
\text { therapy prorgram. }\end{array}$ & Waitlist control. & $\begin{array}{l}3,6, \text { and } \\
9 \text { months } \\
\text { after } \\
\text { baseline }\end{array}$ \\
\hline $\begin{array}{l}35(S D= \\
11.1)\end{array}$ & 15 & $\begin{array}{l}\text { Motivational interview session followed by two } \\
\text { shorter telephone follow-up interventions. }\end{array}$ & No control group. & $\begin{array}{l}4-6 \text { weeks } \\
\text { following } \\
\text { initial } \\
\text { interven- } \\
\text { tion }\end{array}$ \\
\hline
\end{tabular}


Table 1. Summary of articles (Continues)

\begin{tabular}{|c|c|c|c|c|c|c|c|}
\hline Study & Location & Participants & Age & $N$ & Intervention description & Control group(s) & Duration \\
\hline \multicolumn{8}{|c|}{ (Counseling Strategies) } \\
\hline $\begin{array}{l}\text { Meglic et al., } \\
2010^{\mathrm{b}}\end{array}$ & Slovenia & $\begin{array}{l}\text { Patients diagnosed } \\
\text { with depression or } \\
\text { mixed anxiety/ } \\
\text { depression for first } \\
\text { time or after a } \\
\text { remission of at } \geq 6 \\
\text { months, with } \\
\text { introduction of } \\
\text { antidepressant } \\
\text { treatment in the last } \\
10 \text { days }\end{array}$ & $\begin{array}{l}\text { Intervention } \\
35.71(S D= \\
12.11) \\
\text { Control } 40.04 \\
(S D=17.07)\end{array}$ & $\begin{array}{l}46 \text { (control } \\
n=25)\end{array}$ & $\begin{array}{l}\text { Online system designed to support } \\
\text { collaborative care management and active } \\
\text { patient engagement; online and phone-based } \\
\text { care management performed by trained } \\
\text { psychologists. }\end{array}$ & $\begin{array}{l}\text { Treatment as usual } \\
\text { (physician visits } \\
\text { and antidepressant } \\
\text { treatment). }\end{array}$ & 6 months \\
\hline Moral et al., 2015 & Spain & $\begin{array}{l}\text { Patients }>65 \text { who } \\
\text { had a chronic disease } \\
\text { and were being } \\
\text { treated by } \\
\text { polypharmacy and } \\
\text { who had a high } \\
\text { probability for non- } \\
\text { adherence }\end{array}$ & 76 & $\begin{array}{l}154 \text { (control } \\
n=84)\end{array}$ & $\begin{array}{l}\text { Providers were trained on patient safety and } \\
\text { medication adherence. They attended a } \\
\text { workshop on motivational interviewing with } \\
\text { content on diverse interactive methodologies. }\end{array}$ & $\begin{array}{l}\text { Providers were } \\
\text { trained on patient } \\
\text { safety and } \\
\text { medication } \\
\text { adherence. }\end{array}$ & 6 months \\
\hline $\begin{array}{l}\text { Pakpour et al., } \\
2015\end{array}$ & Iran & $\begin{array}{l}\text { Epilepsy patients } \\
\text { diagnosed who had } \\
\text { independence in } \\
\text { daily living activities } \\
\text { or responsibility for } \\
\text { taking their } \\
\text { medications }\end{array}$ & $\begin{array}{l}\text { Intervention } \\
41.37(S D= \\
16.25) \\
\text { Control } 39.86 \\
(S D=15.01)\end{array}$ & $\begin{array}{l}275 \text { (control } \\
n=137)\end{array}$ & $\begin{array}{l}\text { Motivational interviewing with three weekly } \\
\text { face-to-face sessions. }\end{array}$ & Standard care. & 6 months \\
\hline
\end{tabular}

aThe study also incorporated patient education in an intervention condition.

${ }^{b}$ The study also incorporated a patient reminder element, either within an intervention or as an opt-in feature. 


\section{Copyrights and Repositories}

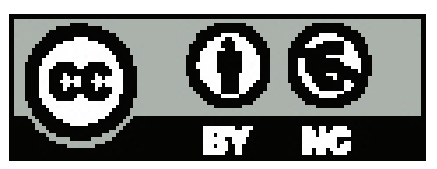

This work is licensed under the Creative Commons Attribution-NonCommercial-3.0 Unported License.

This license allows you to download this work and share it with others as long as you credit the author and the journal. You cannot use it commercially without the written permission of the author and the journal ("Review of Communication Research").

\section{Attribution}

You must attribute the work to the author and mention the journal with a full citation, whenever a fragment or the full text of this paper is being copied, distributed or made accessible publicly by any means.

\section{Commercial use}

The licensor permits others to copy, distribute, display, and perform the work for non-commercial purposes only, unless you get the written permission of the author and the journal.

The above rules are crucial and bound to the general license agreement that you can read at:

http://creativecommons.org/licenses/by-nc/3.0/

\section{Corresponding author}

Kristin G. Maki

Department of Health Services Research,

The University at Texas MD Anderson Cancer Center,

1515 Holcombe Blvd., Unit 437, Houston, TX 77030, USA

kmaki@mdanderson.org

Attached is a list of permanent repositories where you can find the articles published by RCR:

Academia.edu@ @ http://independent.academia.edu/ReviewofCommunicationResearch

Internet Archive@ http://archive.org (collection "community texts")

Social Science Open Access Repository, SSOAR@ @ttps://www.ssoar.info/ssoar/ 